
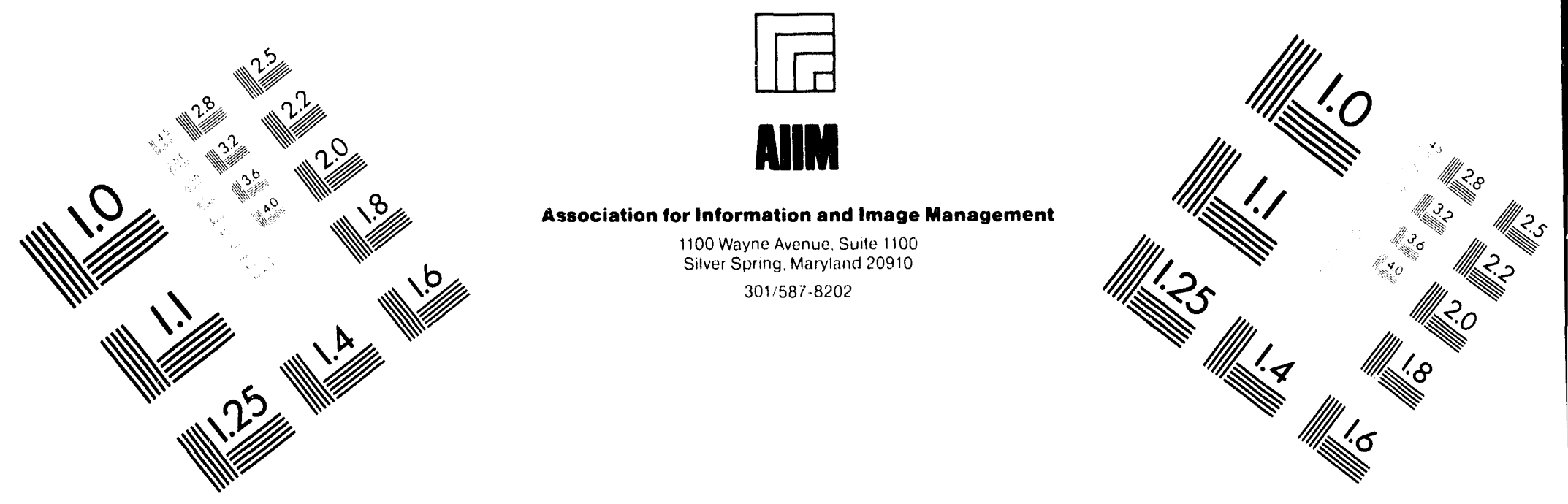

Centimeter

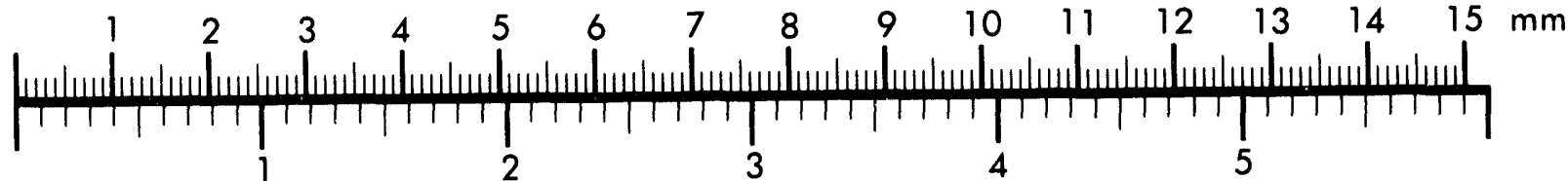
Inches
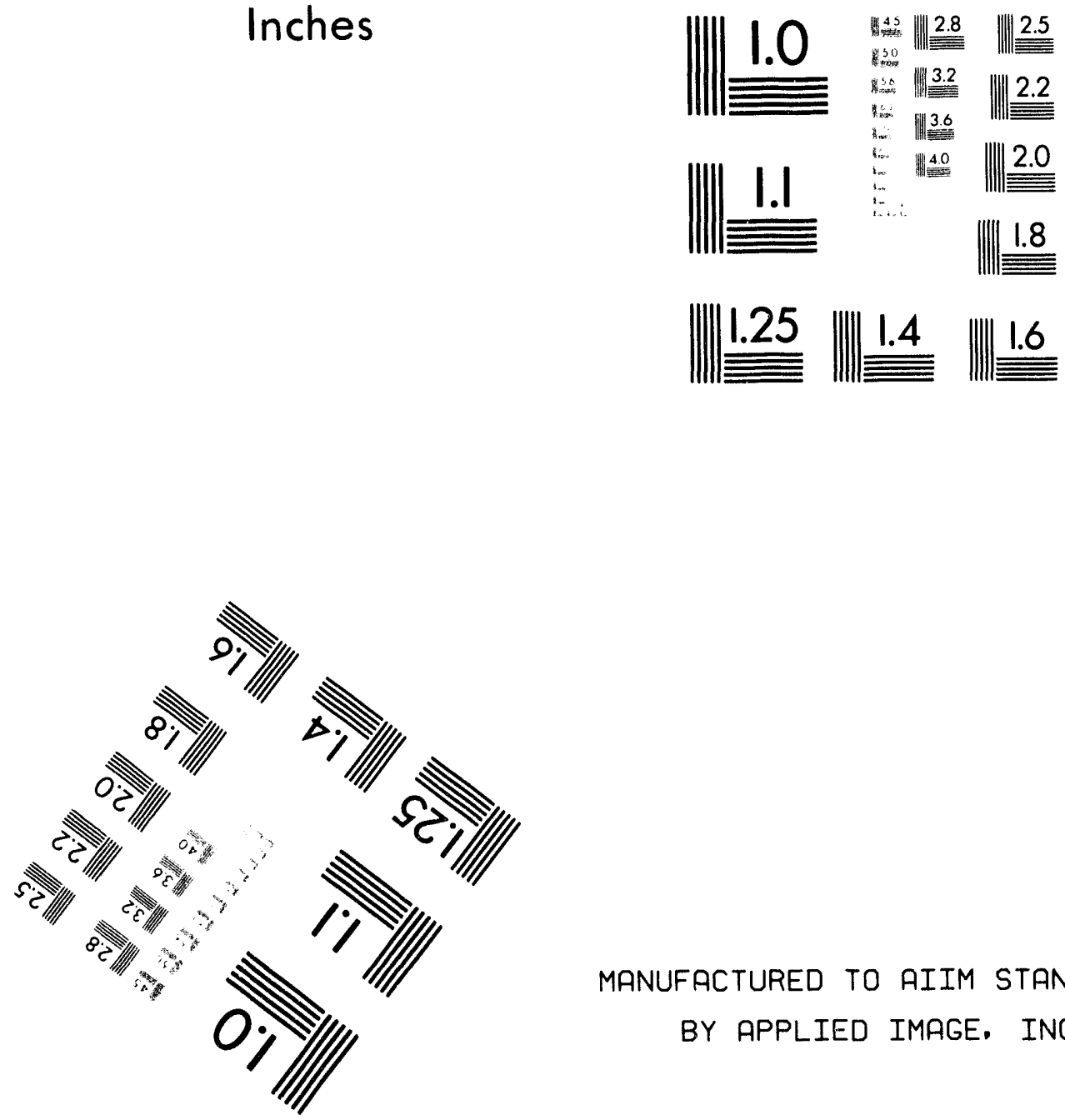

MANUFACTURED TO AIIM STANDARDS

BY APPLIED IMAGE. INC.

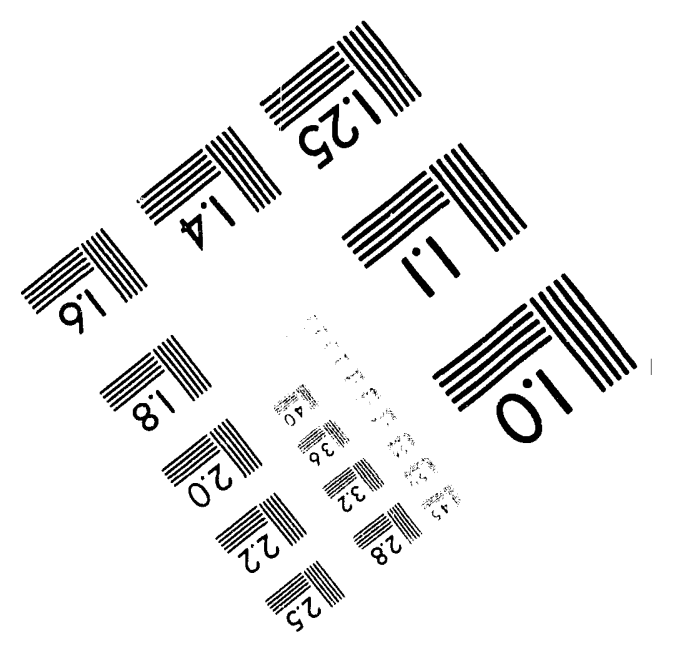



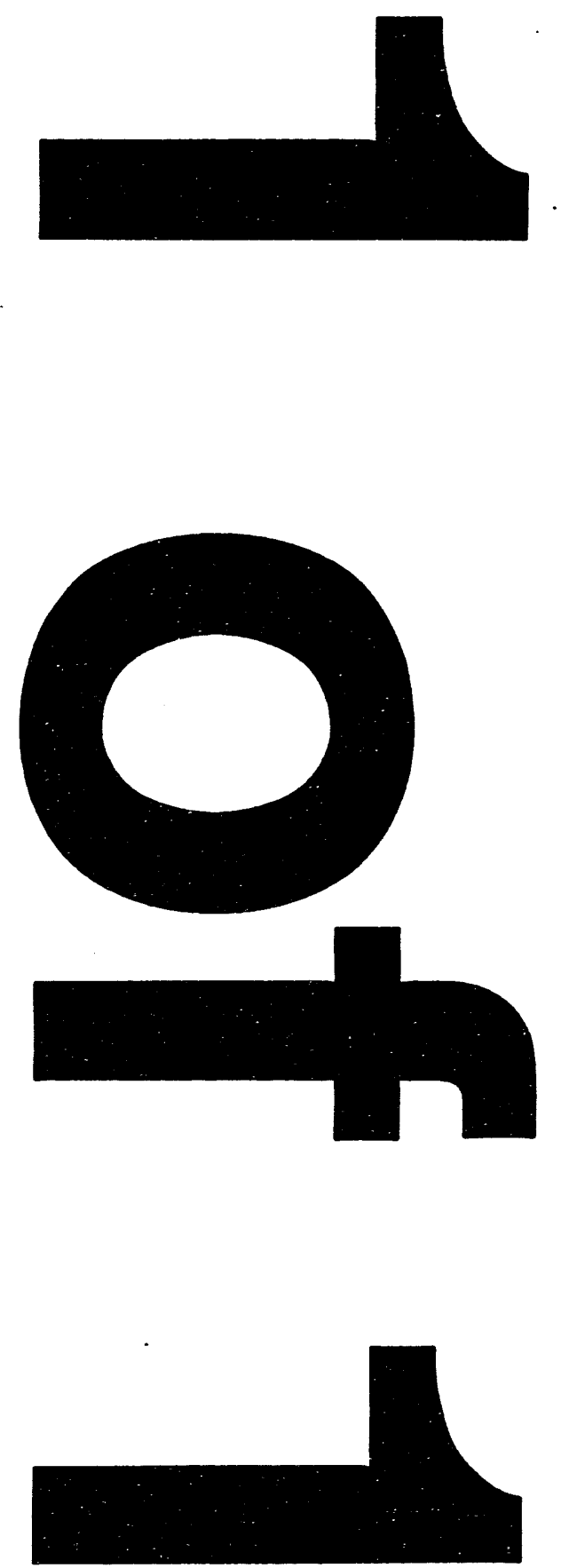


\title{
Evaluation of Existing Hanford Buildings for the Storage of Solid Wastes
}

\author{
M. C. Carlson \\ R. D. Hodgson \\ J. C. Sabin \\ Date Published \\ May 1993
}

Prepared for the U.S. Department of Energy Office of Environmental Restoration and Waste Management 


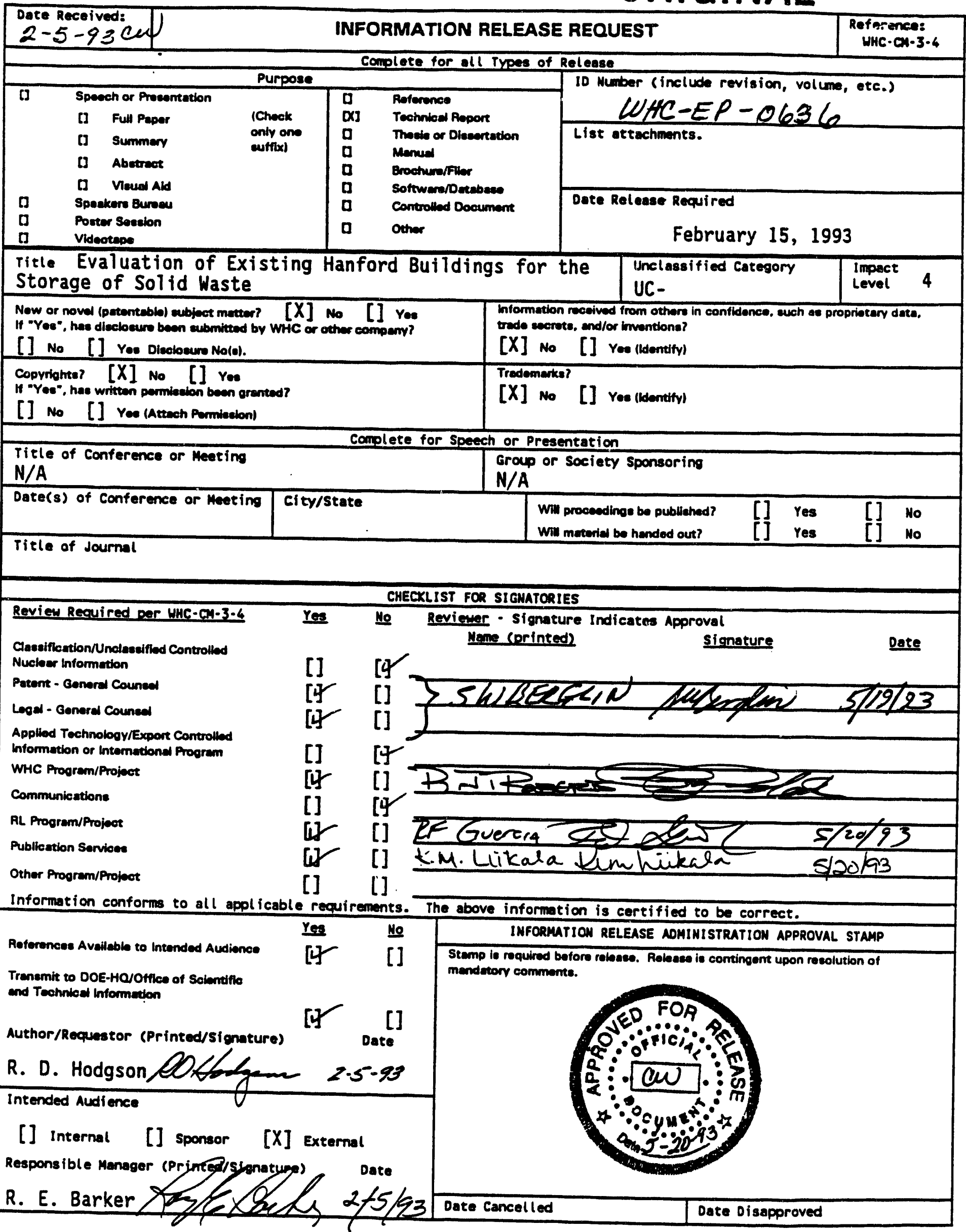


WHC-EP-0636

EVALUATION OF EXISTING HANFORD BUILDINGS FOR

THE STORAGE OF SOLID WASTES

Prepared by:

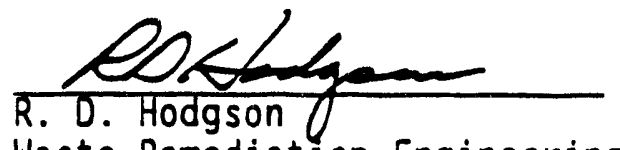

Waste Remediation Engineering

Date $3-11-93$

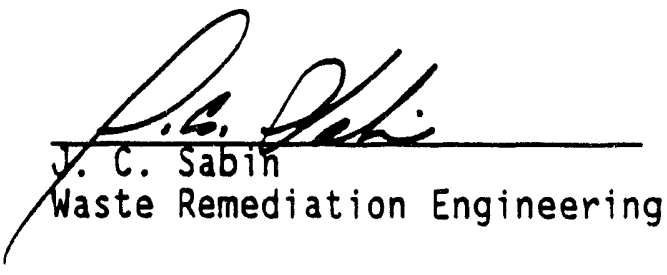

Date $3 \cdot 11-93$

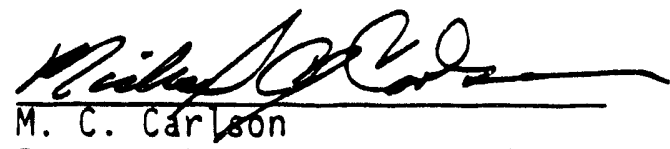

Date $3-(1-93$

Approved by:

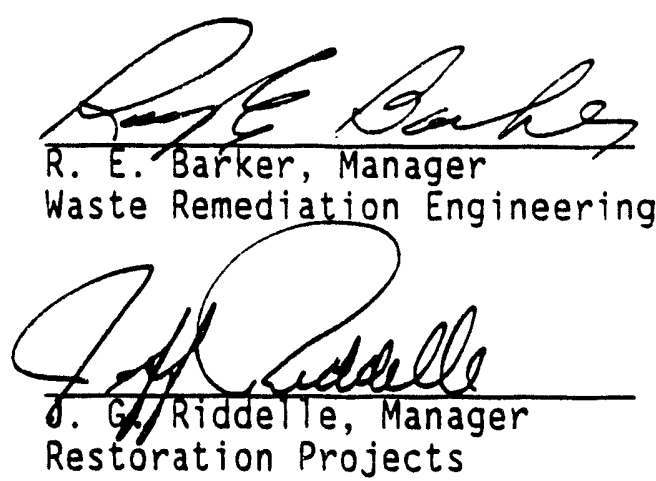

Date $3 / 4 / 93$

Date $3 / 12 / 93$ 
WHC-EP-0636

\section{CONTENTS}

1.0 INTRODUCTION AND SCOPE ................... 1

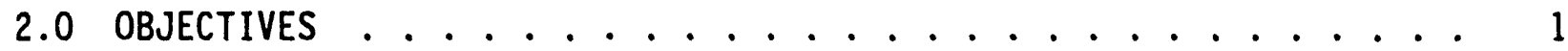

3.0 SUMMARY . . . . . . . . . . . . . . . . . 1

4.0 REGULATORY REQUIREMENTS . . . . . . . . . . . . 2

4.1 WASTE TYPES TO BE STORED ............... 2

4.2 STATE AND RESOURCE AND CONSERVATION AND RECOVERY ACT OF 1976 REQUIREMENTS FOR STORAGE FACILITIES .......... 3

4.3 HANFORD SITE REQUIREMENTS FOR STORAGE FACILITIES . . . . . . 4

5.0 BUILDING SURVEY . . . . . . . . . . . . . . . . 4

5.1 BACKGROUND ..................... 5

5.2 EXISTING FACILITY SELECTION . . . . . . . . . . 5

5.3 INVESTIGATION OF EXISTING FACILITIES . . . . . . . . . . 9

5.4 ESTABLISHING COST COMPARISONS . . . . . . . . . . . 9

5.5 BUILDING EVALUATION AND ESTIMATING CONSIDERATIONS ..... 11

5.6 BUILDING UPGRADE COSTS FOR $2101-M \ldots \ldots$

5.7 COST OF NEW CONSTRUCTION . . . . . . . . . 16

5.8 COST FOR DECONTAMINATION AND DECOMMISSIONING ....... 16

5.9 COST OF UPGRADE COMPARED TO THE COST OF NEW CONSTRUCTION . . . 17

6.0 SPECIFIC FACILITY EVALUATIONS . . . . . . . . . . . . . 19

$6.12101-M, 200$ EAST AREA, OFFICE AND WAREHOUSE FACILITY . . . 19

$6.2275-$ EA WAREHOUSE ESSENTIAL MATERIALS . . . . . . . . 20

$6.3224-B$ CONCENTRATION FACILITY . . . . . . . . . . . . . . 22

$6.4224-$ T FACILITY . . . . . . . . . . . . . . . . 23

6.52721 -EA AIRCRAFT HELICOPTER HANGAR . . . . . . . . 24

$6.6271-$ U OFFICE BUILDING . . . . . . . . . . . . . . 24

6.7427 FUEL AND MATERIAL EXAMINATION FACILITY . . . . . . . 25

6.8437 MAINTENANCE AND STORAGE FACILITY . . . . . . . . . 26

$6.9221-U$ PLANT CANYON BUILDING $\ldots . . . . . . . . .26$

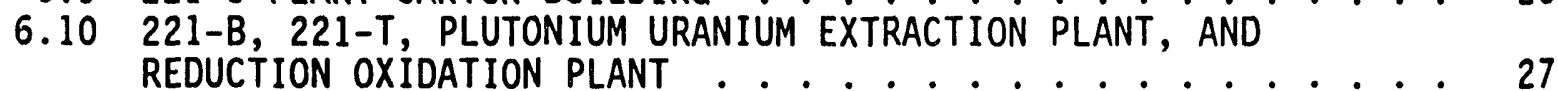

$6.11231-2$ MATERIAL ENGINEERING LABORATORY . . . . . . . . . . 27

$6.124732-A, 4732-B$, AND $4732-C$ FAST FLUX TEST
FACILITY WAREHOUSES . . . . . . . . . . . . . . 28

7.0 REFERENCES ............................ 28 


\section{LIST OF FIGURES}

1 Cost Comparison Criteria . . . . . . . . . . . . . 12

2 2101-M Warehouse Layout ................ 13

3 Building $2101-M \ldots \ldots \ldots 14$

4 Building 2101-M Roof Deterioration ............. 21

\section{LIST OF TABLES}

1 Surplus Facility Listing .................. 6

2 Existing Facilities for the Storage of Solid Waste Reviewed Storage Space of 15,000 $\mathrm{ft}^{2}$ or greater .............. 10

3 Parametric Estimating System Cost Analysis . . . . . . . . 15

4 Cost Comparison of Existing Facility Modification Versus New Facility Construction .................. 17 


\section{LIST OF TERMS}

$\begin{array}{ll}\text { ALARA } & \text { as low as reasonably achievable } \\ \text { CFR } & \text { Code of Federal Regulations } \\ \text { Ci } & \text { Curie } \\ \text { CWC } & \text { Central Waste Complex } \\ \text { D\&D } & \text { Decontamination and decommissioning } \\ \text { DOE } & \text { U.S. Department of Energy } \\ \text { ECOlogy } & \text { Washington State Department of Ecology } \\ \text { EPA } & \text { U.S. Environmental Protection Agency } \\ \text { FFTF } & \text { Fast Flux Test Facility } \\ \text { FMEF } & \text { Fuels and Materials Examination Facility } \\ \text { FY } & \text { fiscal year } \\ \text { HVAC } & \text { heating, ventilation, and air conditioning } \\ \text { KEH } & \text { Kaiser Engineers Hanford } \\ \text { LLW } & \text { low-level waste } \\ \text { LLMW } & \text { low-level mixed waste } \\ \text { LL/TRU MW } & \text { low-level and/or transuranic mixed waste } \\ \text { MASF } & \text { Maintenance and Storage Facility } \\ \text { PNL } & \text { Pacific Northwest Laboratory } \\ \text { PUREX } & \text { Plutonium-Uranium Extraction } \\ \text { RCRA } & \text { Resource Conservation and Recovery Act of } 1976 \\ \text { REDOX } & \text { Reduction Oxidation } \\ \text { SAF } & \text { Secure Automated Fabrication } \\ \text { SWP } & \text { Special Work Procedure } \\ \text { TRU } & \text { transuranic } \\ \text { TRUSAF } & \text { Transuranic Waste Storage and Assay Facility } \\ \text { WAC } & \text { Washington Administrative Code } \\ \text { WHC } & \text { Westinghouse Hanford Company } \\ \text { WRAP } & \text { Waste Receiving and Processing } \\ & \end{array}$




\section{EXECUTIVE SUMMARY}

Existing storage space at the Hanford Site for solid low-level mixed waste (LLMW) will be filled up by 1997. Westinghouse Hanford Company (WHC) has initiated the project funding cycle for additional storage space to assure that new facilities are available when needed.

In the course of considering the funding request, the U.S. Department of Energy (DOE) has asked WHC to identify and review any existing Hanford Site facilities that could be modified and used as an alternative to constructing the proposed W-112 Project. This report documents the results of that review.

In summary, no buildings exist at the Hanford Site that can be utilized for storage of solid LLMW on a cost-effective basis when compared to new construction.

The nearest approach to an economically sensible conversion would involve upgrade of $100,000 \mathrm{ft}^{2}$ of space in the 2101-M Building in the 200 East Area. Here, modified storage space is estimated to cost about $\$ 106 \mathrm{per} \mathrm{ft}^{2}$ while new construction will cost about $\$ 50$ per $\mathrm{ft}^{2}$. Construction costs for the waste storage portion of the W-112 Project are comparable with W-016 Project actual costs, with escalation considered. Details of the cost evaluation for this building and for other selected candidate facilities are presented in this report. All comparisons presented address the potential decontamination and decommissioning (D\&D) cost avoidances realized by using existing facilities. 
The primary reasons that efforts to modify and reuse such facilities are seldom practical are: (1) the existing facilities are usually old, deteriorated, and ill-maintained, (2) they were very specifically designed for unique tasks without consideration for expansion or multi-purpose use, and (3) most were built according to codes and standards that have been supplanted by newer requirements that are more restrictive and costly to meet; attempts at upgrade fall subject to the new requirements.

This study does not attempt to evaluate any cost alternatives involving wavers that would reduce U.S. Environmental Protection Agency (EPA) storage requirements that currently prevent the utilization of surplus Hanford Site facilities in their current condition. 


\subsection{INTRODUCTION AND SCOPE}

In support of the change in mission at the Hanford site, the U.S. Department of Energy (DOE) has requested Westinghouse Hanford Company (WHC) to investigate the feasibility and costs of using existing Hanford Site facilities for storage of solid wastes. In response, WHC has evaluated the use of existing Site buildings for storage of solid waste in lieu of constructing approximately $72,000 \mathrm{ft}^{2}$ of new storage space planned for 1997.

Sections 1, 2, and 3 discuss the Scope, Objective, and Summary respectively. Waste types to be stored and the regulatory requirements for solid waste storage are discussed in Section 4. Section 5 discusses the building survey, the selection of the sample facility, the cost estimate upgrading the sample facility, and a cost comparison between the use of existing facilities and building new facilities. A discussion of the different facilities that were investigated is in Section 6 .

\subsection{OBJECTIVES}

The objective is to locate an existing Hanford Site building that has been maintained in a reasonably good state of repair, estimate the cost of converting the building to a Resource Conservation and Recovery Act of 1976 (RCRA) approved storage facility, and compare the conversion cost with the cost of constructing a new storage facility. The cost estimates are to include decommissioning the facilities at the end of the mission.

This study does not attempt to evaluate any cost alternatives involving negotiated wavers that would reduce U.S. Environmental Protection Agency (EPA) storage requirements that currently prevent the utilization of surplus Hanford Site facilities in their current condition. To utilize any of the facilities, alternative guidelines would be required to established which of the storage requirements would require waivers.

\subsection{SUMMARY}

From the Hanford Site inventory of just under 2,000 buildings, 99 were initially identified as feasible candidates for consideration as waste storage space. This group was then further screened on the basis of physical characteristics, including size and layout adaptability, to produce the list of 20 that are further addressed in this report.

Evaluation of construction details, clean out costs, current use, and particularly contamination status for the 20 structures rather clearly identified the 2101-M Building as the optimum study candidate. 
For this study, Kaiser Engineers Hanford (KEH) performed a detailed cost estimate for upgrading $100,000 \mathrm{ft}^{2}$ of the space in $2101-M$ to storage that would meet state and Federal requirements. This information, and costs for construction of new warehousing space, are summarized below.

\begin{tabular}{|l|r|r|}
\hline \multicolumn{1}{|c|}{ Activities } & $2101-M$ Warehouse & $\begin{array}{c}\text { New warehouse } \\
\text { facility }\end{array}$ \\
\hline Initial decontamination costs & Not required & Not required \\
\hline Asbestos removal cost & $\$ 540,000$ & Not required \\
\hline Upgrade or new construction costs & $\$ 10,100,000$ & $\$ 5,038,000$ \\
\hline D\&D costs & $\$ 133,000$ & $\$ 806,000$ \\
\hline Totals & $\$ 10,773,000$ & $\$ 5,844,000$ \\
\hline Storage space cost per $\mathrm{ft}^{2}$ & $\$ 108$ & $\$ 58$ \\
\hline
\end{tabular}

No other unused Hanford Site buildings with sufficient storage capacity can be converted and upgraded more economically than 2101-M.

Thus, upgrade costs to bring existing unused Hanford Site facilities into compliance with all RCRA and DOE requirements for solid waste storage are significantly higher than cost for new construction.

\subsection{REGULATORY REQUIREMENTS}

The Hanford Solid Waste Management Program has established a long-range strategy to ensure that solid waste management at the Hanford Site is compliant with state and Federal laws and DOE directives. The storage portion of the strategy includes phased construction of storage facilities for lowlevel waste (LLW) and transuranic (TRU) solid waste while awaiting treatment or disposal. Waste containers to be stored may contain hazardous materials as defined by Code of Federal Regulations (CFR), 40 CFR 261 or dangerous and extremely hazardous waste as defined in Washington Administration Code (WAC) 173-303-070 through 173-303-103.

\subsection{WASTE TYPES TO BE STORED}

Existing storage facilities that support the Waste Receiving and Processing (WRAP) Facilities are low-hazard facilities and are intended to store waste with limited amounts of plutonium and/or fission products. These wastes include TRU wastes as well as some LLW and wastes that could potentially be classified as Category 3 LLW or as greater that Category 3 LLW (GTC3) in accordance with 10 CFR 61. 
Long-term storage facilities will be necessary to store the following, higher activity waste categories, which will require moderate-hazard waste storage facilities:

- Low-Level Category 3 waste (LLW Category 3)

- Low-Leve1 Greater than Category 3 waste (LLW GTC3)

- Low-Leve1 Mixed Category 3 waste (LLMW Category 3)

- Low-Level Mixed Greater than Category 3 waste (LLMW GTC3)

- TRU and retrieved suspect TRU waste

- TRU and retrieved suspect TRU mixed waste.

Waste not fully characterized, such as waste exhumed from burial grounds, will be considered dangerous waste and must be placed in overpack containers and stored in RCRA approved storage facilities. The overpack requirement was derived from a RCRA requirement that wastes must be appropriately characterized before entering the storage facility. The overpack requirement plus good primary container integrity prevents commingling of potentially incompatible wastes and is expected to preclude the need for precharacterization before the waste is placed in the storage facility.

\subsection{STATE AND RESOURCE AND CONSERVATION AND RECOVERY ACT OF 1976 REQUIREMENTS FOR STORAGE FACILITIES}

A facility that stores dangerous or mixed waste for over 90 days, may do so only if the facility has received either an "interim status" permit or a "final facility" permit from Ecology and the EPA. Interim status can be obtained by filing a Part A Permit Application with Ecology while being in compliance with the Dangerous Waste Regulations. Submittal of a Part B Permit Application is also required, in accordance with the schedules in the Hanford Federal Facility Agreement and Consent Order (Tri-Party Agreement) (Ecology et al. 1992).

A final facility permit is obtained by the approval of a Part B Permit Application by Ecology and EPA, Region 10. A Facility is permitted to operate under interim status until a final facility permit is approved. New dangerous waste storage facilities may require the Part $B$ permit to be approved before construction and operation.

The following are some of the dangerous waste regulations required by Ecology that would directly impact the selection of an existing facility for the storage of solid waste.

- WAC 173-303-s95(4) Loading and unloading areas. "TSD facilities which receive or ship manifested shipments of liquid dangerous waste for treatment, storage or disposal must provide for and use an area for loading and unloading waste shipments. The loading and unloading area must be designed, constructed, operated and maintained to: (a) Contain spills and leaks that might occur during loading or unloading; (b) Prevent release of dangerous waste or dangerous waste constituents to ground or surface waters; (c) Contain wash waters (if any) resulting from the cleaning of contaminated transport vehicles and load/unload equipment; and (d) Allow for removal, as soon as possible, of collected wastes 
resulting from spills, leaks and equipment cleaning (if any) in a manner which assures compliance with this subsection."

- WAC 173-303-630(5)(c) [Management of containers] "A minimum thirtyinch separation is required between aisles of containers holding dangerous waste(s). A row of drums must be no more that two drums wide."

- WAC 173-303-630(6) Inspections. "At least weekly, the owner or operator must inspect areas where containers are stored, looking for leaking containers and for deterioration of containers and the containment system caused by corrosion, deterioration or other factors."

- WAC 173-303-630(7)(a) [Containment] "Container storage areas must have a containment system that is capable of collecting and holding spills and leaks...." [Note: This includes water from the discharge of the fire protection system]

- WAC 173-303-630(7)(a)(iii) [Containment] "Have sufficient capacity to contain ten percent of the volume of all containers or the volume of the largest container, whichever is greater. ...."

- WAC 173-303-630(10) Closure "At closure, all dangerous waste and dangerous waste residues must be removed from the containment system. Remaining containers, liners, bases, and soil containing or contaminated with dangerous waste or dangerous waste residues must be decontaminated or removed."

The storage requirements for ignitable or reactive wastes (WAC 173-303-630(8), and incompatible wastes (WAC 173-303-630(9) are referenced here; however, this study does not consider the storage of these wastes in existing facilities.

\subsection{HANFORD SITE REQUIREMENTS FOR STORAGE FACILITIES}

The WHC Dangerous Waste Control Program is defined in Environmental Compliance, WHC-CM-7-5, Part I, "Dangerous Waste Control" and Part J, "Mixed Waste." This program ensures WHC compliance with Washington State Dangerous Waste Regulations Contained in WAC 173-303, The EPA regulations contained in 40 CFR 260-268, and the requirements imposed by DOE Order 5400.0. Mixed waste is defined as waste containing both radioactive and hazardous components as defined by the Atomic Energy Act of 1954 and RCRA respectively.

\subsection{BUILDING SURVEY}

This section discusses the logic used to assemble the cost comparison between upgrading an existing building and constructing a new building. Included, is the method for selecting the candidate buildings, the background 
WHC-EP-0636

information on the general condition of the facilities, and the evaluation method used to determine the comparison costs.

\subsection{BACKGROUND}

This study reviewed the possibility of utilizing one or more surplus Hanford Site facilities for the temporary storage of waste in an attempt to reduce site costs and minimize the potential for contaminating additional facilities.

The study reviewed the RCRA requirements currently being imposed on storage facilities, together with the DOE Order 6430.1A that specifies minimum requirements for DOE facilities. These requirements result in significant cost penalties if older structures are to be upgraded for use as temporary storage facilities.

When these nuclear facilities were closed down over the past 25 years, the maintenance budget to maintain many of these structures in a safe condition was effectively eliminated from the operating budgets. Because of the lack of maintenance, these structures fell into a state of disrepair. The condition of the majority of the old structures is very poor. Roofs are in need of repair, and in many instances, are unsafe to walk on. Asbestos insulation, siding, and roofing materials were used extensively in the construction of these facilities. In some of the buildings, the internal process hardware contains highly contaminated heating, ventilation, and air conditioning (HVAC) systems, process piping systems, vessels, and equipment, many of which are still installed in the buildings.

The electrical systems are very old, unreliable, outdated spare parts are not available, and in many cases, these systems do not comply with current National Electrical Code requirements. Upgrading of these older facilities (that are approaching 50 years in age, but were originally designed for a 20 year life) will require a substantial amount of rebuilding. Many of these facilities are process-type structures with individual process cells, designed to provide nuclear shielding, and are not suited to forklift access for the storage of large boxes or drums of waste on forklift pallets. These issues, coupled with the current storage requirements imposing the new RCRA, Safety, and Environmental Standards, can result in extremely expensive decontamination and remodeling costs.

Decontamination and cleanup must be completed before using any of these old structures for waste storage. This cleanup will require a large quantity of up-front dollars to perform this cleanup to state and Federal requirements. In comparison, the actual disposal costs for cleaning up a clean structure would be minimal.

\subsection{EXISTING FACILITY SELECTION}

A surplus facility listing (Table 1) was selected from the Hanford Site building list that contains over 1,970 buildings and facilities. Ninety-nine buildings were selected from the list, based on the current or previous use for the building and on the prospect of using the building for long-term 


\begin{tabular}{|c|c|c|c|c|c|c|c|}
\hline & 427 & 1900 & $105 H$ & 1900R & 437 & 2312 & $108 F$ \\
\hline FLOOR SPACE & 216,846 & 90,700 & 74,640 & 63,360 & 60,197 & 38,121 & 31,084 \\
\hline DRAMIMG MO. & SK-4-83004 & $H-1-15153$ & $H-1-41946$ & $H-1-46377$ & $H-4-62392$ & $H-2-33169$ & $H-1-03168$ \\
\hline STRUCTURAL MATERIAL & conc. & CONC. BLK & conc. & SHT. MTL. & SHT. MTL. & CONC/BLOCK & ST/CONC/BLOCK \\
\hline STRUCTURAL TYPE & 6-STORY & MULTI.STORY & MULTI.STORY & 1-STORY & 1-STORY & 2-STORY & 4-STORY \\
\hline CURBING & MONE & MONE & MONE & MOWE & MONE & MONE & MONE \\
\hline FORKLIFT ENTRANCE & ROLL DOOR & ROLL DOOR & ROLL DOOR & ROLL DOOR & ROLL DOOR & ROLL DOOR & MO ACCESS \\
\hline ROOF IMTEGRITY & SAFE & UMSAFE & SAFE & $\begin{array}{l}\text { PART. IMSP - } \\
\text { SAFE }\end{array}$ & SAFE & SAFE-LEAKS & POOR/LEAKS \\
\hline PITS, STAIRMELLS, ELEVATOR SHAFTS, ETC. & YES & YES & YES & YES & YES & 4 HOT CELLS & WO ELEVATOR \\
\hline EXISTING CONTAMIMATION & MONE & Haz. & RADIO/HAZ & MOME & RAD 10 & RADIO/HAZ & HAZ \\
\hline ASBESTOS & No & YES & YES & YES & No & YES & YES \\
\hline ELEVATORS & YES & UNKMOMN & YES & MONE & No & NO & No \\
\hline EXCLUSIVE USE & YES & YES & YES & YES & MO & YES & No \\
\hline SHIPPING AND RECEIVING AREA & YES & YES & YES & YES & YES & No & мо \\
\hline UTILITIES & o.k. & SUB COOE & SUB COOE & NO UATER & o.k. & o.k. & MO \\
\hline HVAC & o.k. & SUB COOE & SUB COOE & No & o.k. & $0 . x$. & No \\
\hline ELECTRICAL & o.k. & SUB COOE & SUB COOE & o.k. & o.k. & o.k. & No \\
\hline FIRE DETECTION AMO SUPPRESSION SYSTEMS & YES & SUB CODE & SUB COOE & YES & o.k. & YES & MO \\
\hline CURRENT STATUS & FMEF & ABANDONED & ABAMDONED & Active & MASF & ACTIVE & ABAMDONED \\
\hline FUTURE USE & MONE & MONE & NONE & NOME & PROCESS & & MOME \\
\hline$D \& D$ PLANS & NO DED PLANS & NO DRD PLAHS & NO D\&D PLANS & Y 1993 & $\begin{array}{l}\text { MO D\&D } \\
\text { PLANS }\end{array}$ & NO DRD PLANS & MO DRD PLAMS \\
\hline DISQUALIFICATION REASON & $\begin{array}{l}\text { MOT CONSTR. } \\
\text { FOR FORKLIFT } \\
\text { OR STORAGE }\end{array}$ & $\begin{array}{l}\text { STRUCTURAL } \\
\text { PROBLEMS }\end{array}$ & $\begin{array}{l}\text { HIGH COST OF } \\
\text { DECCON AND } \\
\text { UPGRADE }\end{array}$ & $\begin{array}{l}\text { CAVERN AREA } \\
\text { UMDER MAIN } \\
\text { FLOOR }\end{array}$ & $\begin{array}{l}\text { IN USE FOR } \\
\text { FFTF } \\
\text { SUPPORT }\end{array}$ & $\begin{array}{l}\text { PU CONTAM. } \\
\text { NOT BUILT } \\
\text { FOR STORAGE }\end{array}$ & $\begin{array}{l}\text { BLDG. AND } \\
\text { STRUCTURAL } \\
\text { PROBLEMS }\end{array}$ \\
\hline
\end{tabular}




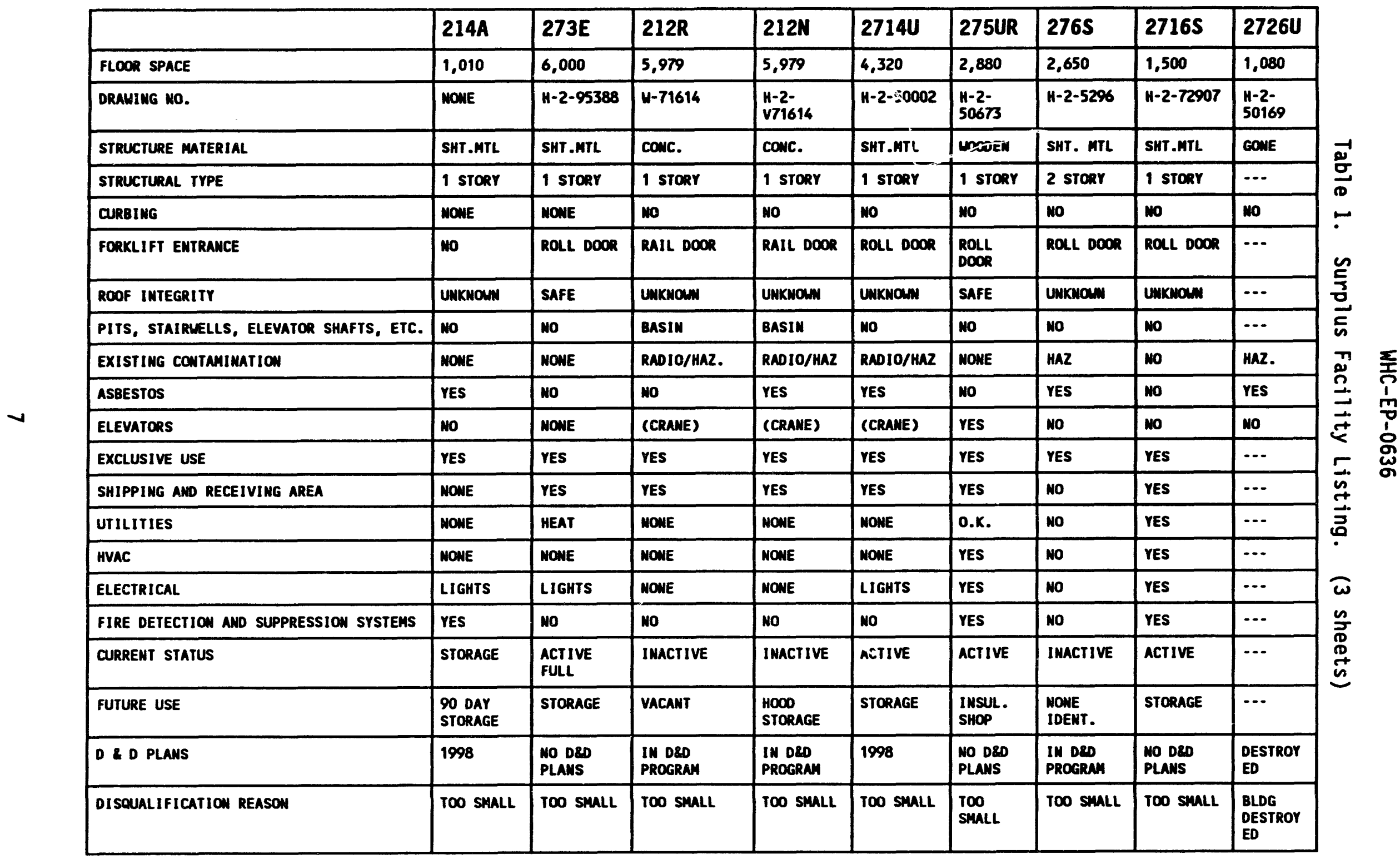




\begin{tabular}{|c|c|c|c|c|c|c|}
\hline & $2101 M$ & 275EA & $224 T$ & $224 B$ & 2710 & 2721EA \\
\hline FLOOR SPACE & 169,320 & 36,000 & 32,300 & 32,300 & 30,700 & 25,600 \\
\hline DRAUING No. & $H-2-71509$ & $H-2-3081$ & H-2-1763 & $\mathrm{H}-2-77540$ & $\mathrm{H}-2-50604$ & H-2-80748 \\
\hline STRUCTURE MATERIAL & SHT. MTL & w000 & conc & conc. & conc. & SHT. MTL \\
\hline STRUCTURAL TYPE & 1 STORY & 1 story & 3-STORY & 3-STORY & 3 storY & 1 story \\
\hline CURBIMG & NOME & NOME & NOME & NOWE & MONE & MONE \\
\hline FORKLIFT ENTRANCE & ROLL DOOR & ROLL DOOR & No & NO & ROLL DOOR & ROLL DOOR \\
\hline ROOF INTEGRITY & UNSAFE & UNSAFE & $\begin{array}{l}\text { PART. INSP - } \\
\text { UWSAFE }\end{array}$ & UNKNOWN & UNKNOWN & SAFE \\
\hline PITS, STAIRUELLS, ELEVATOR SHAFTS, ETC. & YES & NONE & UnKNOM & STM UNSAFE & UnKNow & MONE \\
\hline EXISTING CONTAMIMATION & Haz. & HAz. & Haz. & HAz. & HAZ. & MONE \\
\hline ASBESTOS & YES & YES & YES & YES & YES & no \\
\hline ELEVATORS & NOWE & No & YES & YES-1940 & YES & no \\
\hline EXCLUSIVE USE & Mo & YES & VES & YES & YES & YES \\
\hline SHIPPING AMD RECEIVING AREA & YES & YES & MO & No & No & YES \\
\hline UTILITIES & o.k. & NONE & o.k. & SUB COOE & o.k. & o.k. \\
\hline HVAC & мо & No & o.k. & SUB COOE & o.k. & o.k. \\
\hline ELECTRICAL & o.k. & o.k. & o.k. & SUB COOE & o.k. & o.k. \\
\hline FIRE DETECTIOW AND SUPPRESSIOW SYSTEMS & YES & YES & o.k. & SUB COOE & o.k. & o.k. \\
\hline CURRENT STATUS & ACTIVE & ACTIVE & TRUSAF & SURPLUS & ACTIVE & ACTIVE \\
\hline FUTURE USE & STORAGE/OFC & STORAGE & PROCESS & OFFICES & OFFICES & FIRE MAINT. \\
\hline D\& D PLANS & Y2000 & NO DRD PLAMS & NO D\&D PLANS & $\begin{array}{l}\text { IN DRD } \\
\text { PROGRAM }\end{array}$ & NO DED PLAMS & MO DRD PLANS \\
\hline DISOUALIFICATION REASON & $\begin{array}{l}\text { CLOSE } \\
\text { PROXIMIYY TO } \\
\text { MANOR OFFICE } \\
\text { BUILDINGS }\end{array}$ & $\begin{array}{l}\text { YOOOEN } \\
\text { STRUCTURE }\end{array}$ & $\begin{array}{l}\text { MULTILEVEL, } \\
\text { LIMITED } \\
\text { FORLIFT } \\
\text { ACCESS }\end{array}$ & $\begin{array}{l}\text { MULTILEVEL, } \\
\text { LIMITED } \\
\text { FORKIFT } \\
\text { ACCESS }\end{array}$ & $\begin{array}{l}\text { MULIILEVEL, } \\
\text { LIMITED } \\
\text { FORLIFT } \\
\text { ACCESS }\end{array}$ & $\begin{array}{l}\text { HANGER DOOR } 8 \\
\text { SLOPED FLOOR } \\
\text { REPLACEMENT }\end{array}$ \\
\hline
\end{tabular}


storage. Warehouse buildings were given primary consideration; however, other types of buildings were considered, depending on size, age, availability, or original use. After the initial survey of the facilities, buildings with less than 15,000 $\mathrm{ft}^{2}$ of floor space were el iminated because of the costs of upgrading and licensing each building, resulting in the facilities listing in Table 2.

\subsection{INVESTIGATION OF EXISTING FACILITIES}

Drawings for facilities listed in Table 2 were obtained and reviewed to evaluate their capability for storing the radioactive and mixed waste and to estimate the costs associated with remodeling these facilities to comply with the RCRA storage requirements.

The type of structure, material handling capability, truck and/or rail access for waste retrieval, design floor loading capability, floor slope, drains, contamination levels, confinement capability, and the air handling equipment required to provide four air changes per hour were analyzed. The costs associated with the removal of in-place radioactive contamination and/or hazardous waste contained within the process equipment, vessels, and piping were evaluated. Hazardous and contaminated waste types and levels, and asbestos insulation, siding, and roofing were also considered. Field trips were conducted to confirm the status and condition of these structures, and the responsible facility landlords were interviewed to gain additional details regarding these facilities, their present status, future usage, and general condition.

\subsection{ESTABLISHING COST COMPARISONS}

To compare the cost of upgrading an available existing facility with the cost of constructing a new facility, a cost comparison table was devised that includes the costs associated with each approach. If an existing facility is upgraded, the following costs are involved:

- Decontamination (if contaminated with radioactive or hazardous materials.)

- Upgrading of the building, which may include removal and replacement of obsolete or sub-standard equipment or systems,

- Final decontamination and decommissioning (D\&D) of the building when mission is completed. 
Table 2. Existing Facilities for the Storage of Solid Waste Reviewed Storage Space of $15,000 \mathrm{ft}^{2}$ or greater.

\begin{tabular}{|c|c|c|c|}
\hline Building number & Area & Building name & $\mathrm{Ft}^{2}$ \\
\hline $4732 A$ & 400 & Warehouse & 15,000 \\
\hline 190DA & 1000 & $\begin{array}{l}\text { Main process pumphouses annex - } \\
\text { abandoned }\end{array}$ & 17,045 \\
\hline $4732 C$ & 400 & Warehouse & 20,000 \\
\hline 4732B & 400 & Warehouse & 24,000 \\
\hline 2721EA & $200 E$ & Helicopter support facility & 25,600 \\
\hline 2710 & $200 W$ & $\mathrm{Pu}$ storage & 30,700 \\
\hline $108 \mathrm{~F}$ & $100 \mathrm{~F}$ & Biology Laboratory - abandoned & 31,084 \\
\hline 224B & $200 E$ & Storage building & 32,300 \\
\hline $224 T$ & $200 W$ & $\begin{array}{l}\text { Transuranic storage and assay } \\
\text { facility }\end{array}$ & 32,300 \\
\hline 275EA & $200 \mathrm{E}$ & $\begin{array}{l}\text { Warehouse essential materials, } \\
\text { north of PUREX }\end{array}$ & 36,000 \\
\hline 2312 & $200 W$ & Materials engineering laboratory & 38,121 \\
\hline $105 \mathrm{~F}$ & $100 \mathrm{~F}$ & Reactor facility - abandoned & 54,600 \\
\hline 105D & 1000 & Reactor facility - abandoned & 55,542 \\
\hline 105DR & 1000 & Reactor facility - abandoned & 58,300 \\
\hline 437 & 400 & $\begin{array}{l}\text { Maintenance and storage facility } \\
\text { (MASF) }\end{array}$ & 60,197 \\
\hline 190DR & 1000 & $\begin{array}{l}\text { Main pumphouse - includes } \\
\text { north/south annex - abandoned }\end{array}$ & 63,360 \\
\hline $105 \mathrm{H}$ & $100 \mathrm{H}$ & Reactor facility - abandoned & 74,640 \\
\hline 1900 & 1000 & Main process pumphouse - abandoned & 90,700 \\
\hline $2101-M$ & $200 E$ & $\begin{array}{l}\text { Spare parts warehouse, office } \\
\text { building }\end{array}$ & 169,320 \\
\hline 427 & 400 & $\begin{array}{l}\text { Fuels and materials examination } \\
\text { facility }\end{array}$ & 216,846 \\
\hline
\end{tabular}


If a new building is constructed instead of utilizing an existing building, the following costs are involved:

- New building construction costs

- Final D\&D of the new building when mission completed,

- Final D\&D of the existing building (that was not utilized).

This cost comparison equation is shown in Figure 1 .

\subsection{BUILDING EVALUATION AND ESTIMATING CONSIDERATIONS}

A $100,000 \mathrm{ft}^{2}$ portion of the $170,000 \mathrm{ft}^{2}, 2101-\mathrm{M}$ Facility was selected as being the most suitable comparison facility (Figures 2 and 3 ). The 2101-M Facility is relatively well maintained, and is currently being used as a warehouse and office facility. The 100,000 $\mathrm{ft}^{2}$ area selected is a portion of the warehouse area. Necessary upgrades and estimated costs are shown in Table 3. The estimate was based on small, fixed-price contractors performing the work. The unit costs used to perform this work are consistent with similar work being performed by KEH on other projects on the Hanford Site.

The RCRA storage requirements were evaluated and it was considered necessary to remove and replace the existing segmented concrete floor to provide spill containment, curbs, and drainage to sumps. This required cutting the perimeter concrete in the $100,000 \mathrm{ft}^{2}$ area to free it from the foundation, jack hammer the slab into small sections, and slab removal. The new replacement concrete slab would be installed with the required slope, drainage, and liquid collection sumps. The floor would be painted with sealant to close all minute cracks that might appear in the new concrete. The air handling equipment required for four air changes per hour was added. Allowances were made for electrical upgrades necessary to provide a computerized inventory accountability system that is required at all storage sites, alarms and warning devices, and lighting upgrades. The engineering costs to prepare the construction packages and the construction management costs to manage the construction were added to the direct costs. Escalation and contingency costs were then added to the estimate using DOE-approved units.

The costs to move and/or dispose of the material currently stored inside this facility were not considered. The costs associated with the disruption of electrical, water, fire protection, HVAC, and sanitary facilities in the office area, and how this affects the day-to-day operations of the office personnel sharing the remaining portion of this building while these construction activities are being completed were not considered.

The question of having other operating, laboratory, and office personnel sharing a common building with stored nuclear waste material was also questioned. After the estimate was completed, this concern was discussed with WHC Safety. Safety stated that buffer zones are required to provide physical separation between a waste storage area and personnel not directly associated with the day-to-day operation of the facility. Based on these buffer zone 


\section{Cost Comparison Criteria}

Cost Of Upgrading Old Buildings

- Cleanup Of Building

$\pi$

- Upgrade Of Building

Plus

- D\&D Of Old Building
Cost Of New Construction

- Construction Costs

Plus

$\leq \quad \bullet \quad$ D\&D Of New Building

Plus

- D\&D Of Old Building 
WHC-EP-0636

Figure 2. 2101-M Warehouse Layout.

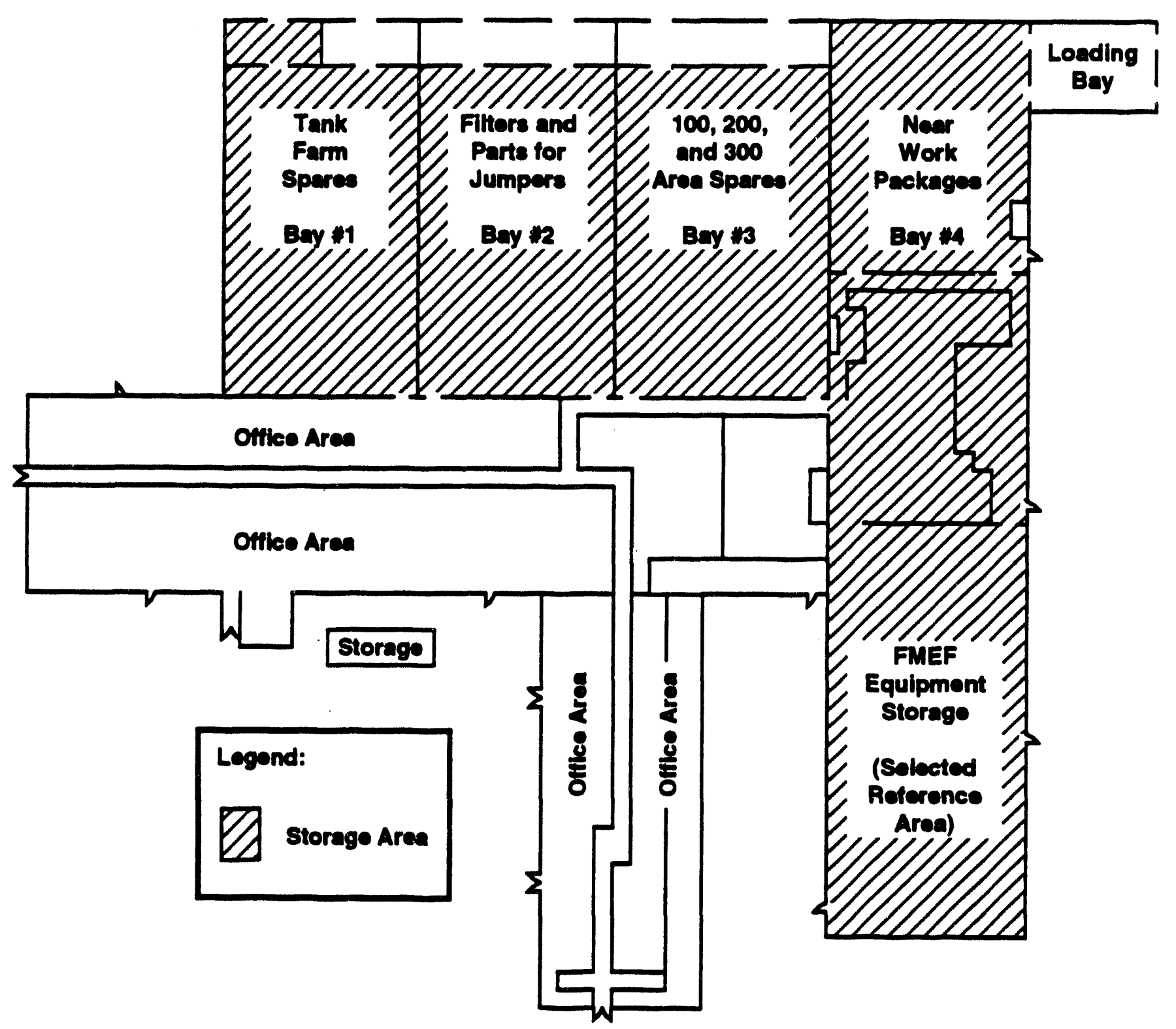

79301184.1 
WHC-EP-0636

Figure 3. Building 2101-M.

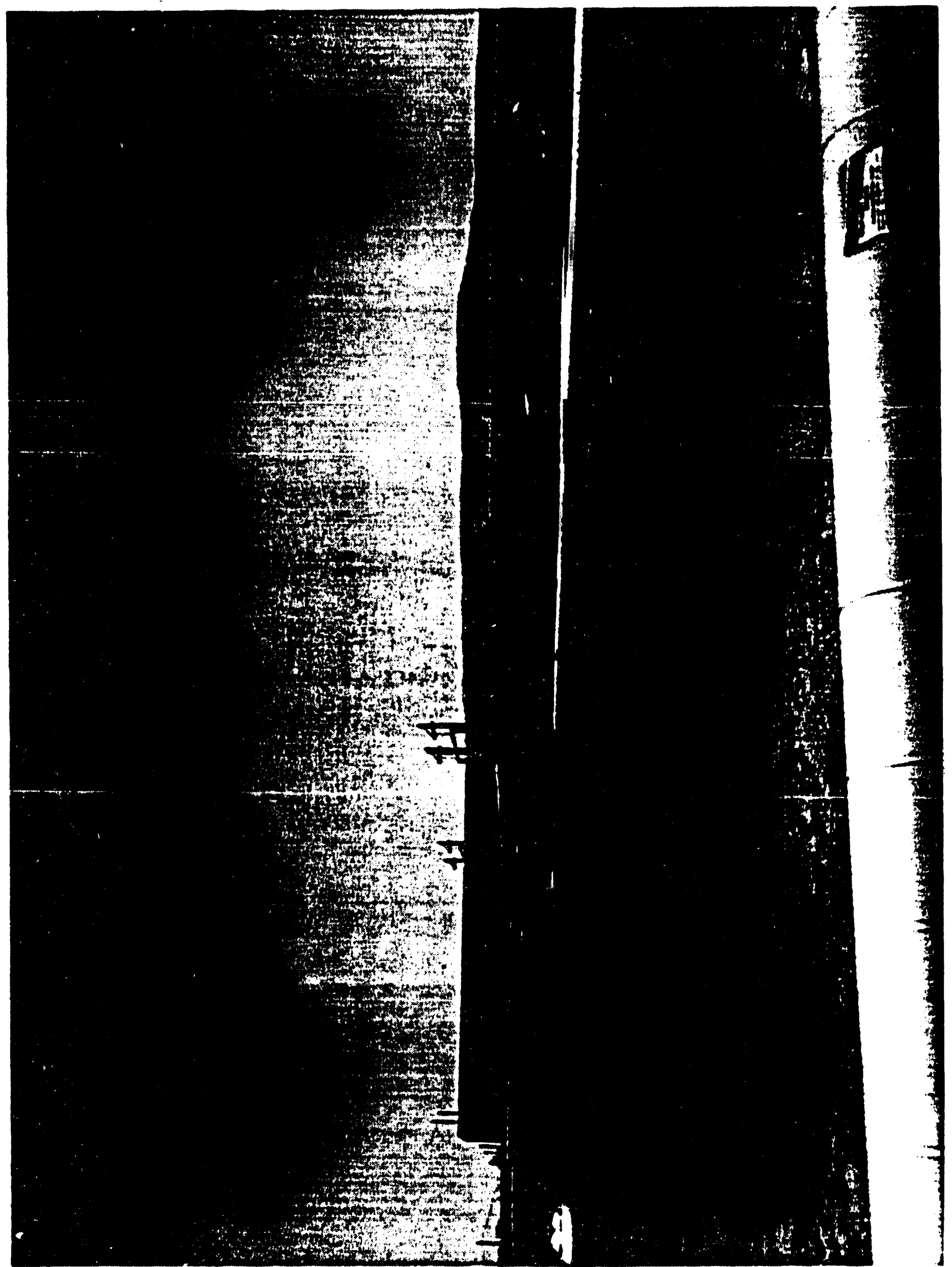


Table 3. Parametric Estimating System Cost Analysis.

\begin{tabular}{|l|c|c|}
\hline \multicolumn{1}{|c|}{ Description } & Cost per $\mathrm{ft}^{2}$ & $\begin{array}{c}\text { Total } \$ \text { for } \\
100,000 \mathrm{ft}^{2}\end{array}$ \\
\hline Roof removal/replace & $\$ 11.73$ & $\$ 1,173,000$ \\
\hline Floor removal/replacement & $\$ 19.92$ & $\$ 1,992,000$ \\
\hline Electrical upgrade & $\$ 10.60$ & $\$ 1,060,000$ \\
\hline $\begin{array}{l}\text { Asbestos/hazardous material } \\
\text { removal/replacement }\end{array}$ & $\begin{array}{c}\text { Not included in } \\
\text { estimate }\end{array}$ & $\begin{array}{c}\text { Workscope not } \\
\text { defined }\end{array}$ \\
\hline HVAC upgrade & $\$ 14.67$ & $\$ 1,467,000$ \\
\hline Fire protection upgrade & $\$ 1.67$ & $\$ 163,000$ \\
\hline Engineering & $\$ 18.00$ & $\$ 1,800,000$ \\
\hline $\begin{array}{l}\text { Construction management and } \\
\text { indirects }\end{array}$ & $\$ 13.80$ & $\$ 1,380,000$ \\
\hline Licensing/miscellaneous & $\$ 10.65$ & $\$ 1,065,000$ \\
\hline
\end{tabular}

Total (rounded) amount required for the remodel of $100,000 \mathrm{ft}^{2}$ of the $2101-M$ is $\$ 10,100,000$

KEH Parametric Estimating System costs are based on dollars per square foot to perform remodeling or replacement of building components to comply with building requirements. Comparative costs are based on a structure containing $100,000 \mathrm{ft}^{2}$ of floor space suitable for drum storage.

Assumptions: DOE Orders 6430.1A (DOE 1989) govern building modifications, DOE/HQ waver required to depart from DOE Orders.

Storage facilities would comply with state and EPA requirements.

Dollars and schedule time for radioactive and/or hazardous material clean up and disposal would be available to support storage requirements if existing facilities are used. 
requirements the 2101-M Facility was disqualified as a possible solid waste storage facility. Safety estimated there are approximately 2,000 employees located in various trailers, office buildings and in the 2101-M office area that would be effected. Potential 2101-M Building safety issues were not addressed in this study because it was considered to be outside the defined scope.

\subsection{BUILDING UPGRADE COSTS FOR 2101-M}

Parametric Estimating System cost estimates were prepared by KEH to determine if upgrading a 100,000 $\mathrm{ft}^{2}$ area of the $2101-M \mathrm{Facility}$ to comply with current state and RCRA Requirements and the requirements of DOE Order $6430.1 \mathrm{~A}$, would result in a cost effective alternative to the construction of new facilities.

KEH Parametric Estimating System costs are based on dollars per square foot to perform remodeling or replacement of building components to comply with the above building requirements. The resultant costs are based on upgrading a $100,000 \mathrm{ft}^{2}$ area of the 2101-M Building to a RCRA approved facility for drum storage. The analys is results are shown in Table 3 . The total dollars required to upgrade $100,000 \mathrm{ft}^{2}$ would be $\$ 10,100,000$.

\subsection{COST OF NEW CONSTRUCTION}

The costs of $\$ 50.00$ per $\mathrm{ft}^{2}$ for new construction was taken from the actual costs for the construction of the Phase I, II, III, and IV storage facilities, fabricated under Project W-016, "Radioactive Mixed Waste Storage Facility". The four storage buildings are located at the Central Waste Complex (CWC) in the 200 West Area at the Hanford Site. These storage buildings provide temporary storage for waste exhumed from burial grounds and for newly generated low-level mixed wastes (LLMW) and transuranic mixed waste (LL/TRU MW) that will be processed by the WRAP facilities. These storage buildings meet the requirements for the storage of both radioactive and hazardous wastes.

\subsection{COST FOR DECONTAMINATION AND DECOMMISSIONING}

D\&D must be considered in the planned use of any of the Hanford Site facilities. Decontamination costs depend upon the type of contaminants and the degree of contamination. Decommissioning costs include the destruction and disposal of the building. For this analysis, it was assumed that the selected facility (2101-M Building) will not become contaminated and that the final D\&D costs will include decommissioning only. The D\&D costs to dispose of a facility that is free of hazardous and nuclear contamination is approximately $\$ 1.33$ per $\mathrm{ft}^{2}$. This cost is based on actual contracted costs to remove the 1166 Building at the Hanford Site. The 1166 Building contained $141,900 \mathrm{ft}^{2}$ of warehouse space and the building was demolished on a fixed price contract in 1992 for $\$ 188,000$. This price, however, did not include the cost of removing the roof, which was contaminated with hazardous materials in the form of asbestos impregnated roofing. The cost of removing the roof was approximately $\$ 2,000,000$, or approximately $\$ 14.00$ per $\mathrm{ft}^{2}$. 
Although the 1166 Building was wood construction and the 2101-M Building is a metal frame building with sheet metal siding, the demolition costs for both buildings are assumed to be the equivalent; however, the potential salvage value of the steel in the 2101-M Building structure could reduce the demolition costs.

\subsection{COST OF UPGRADE COMPARED TO THE COST OF NEW CONSTRUCTION}

The cost comparison criteria described in Section 5.4 is used to show how the individual costs associated with upgrading an existing building compares with new construction. Table 4 shows the incremental cost comparison. The comparison involves the initial decontamination costs for existing buildings, modifications and upgrades to existing buildings, cost of construction of new buildings, and the D\&D of both buildings when their missions have been completed.

Table 4. Cost Comparison of Existing Facility Modification Versus New Facility Construction.

\begin{tabular}{|l|l|l|}
\hline \multicolumn{1}{|c|}{ Activities } & \multicolumn{1}{|c|}{$2101-M$ warehouse } & \multicolumn{1}{|c|}{$\begin{array}{c}\text { New warehouse } \\
\text { facility }\end{array}$} \\
\hline Initial recontamination costs & Not required & Not required \\
\hline Asbestos removal cost & $\$ 540,000^{(4)}$ & Not required \\
\hline $\begin{array}{l}\text { Modification and upgrade } \\
\text { costs }\end{array}$ & $\$ 10,100,000^{(1)}$ & Not required \\
\hline Build new facility cost & Not required & $\$ 5,038,000^{(3)}$ \\
\hline $\begin{array}{l}\text { Eventual D\&D of existing } \\
\text { facility cost }\end{array}$ & $\$ 133,000^{(2)}$ & $\$ 673,000^{(5)}$ \\
\hline $\begin{array}{l}\text { Eventual D\&D of new facility } \\
\text { cost }\end{array}$ & Not required & $\$ 133,000^{(2)}$ \\
\hline \hline Total costs & $\$ 10,773,000$ & $\$ 5,844,000$ \\
\hline
\end{tabular}

'KEH estimate, minimum cost to remodel 2101-M Warehouse to comply with EPA and DOE Order 6430.1A (DOE 1989) requirements for solid waste storage facilities.

'Based on actual contracted demolition costs to remove the 1166

Building, work completed November 1992, ahead of schedule and within budget.

Clean out of contaminated materials not included.

${ }^{3}$ Estimate based on actual construction costs for Phase 1 through

Phase IV solid waste storage building escalated to 1995/1996 dollars.

"Estimate taken from Wells and Hughes (1990).

If a new facility is built, D\&D costs for $2101-M$ would also include asbestos removal. 
The results of the comparison indicate that the cost involved in renovating the most suitable Hanford Site facilities to comply with current DOE Order, EPA, and Ecology requirements and regulations will cost approximately twice as much as constructing a new warehouse of equivalent storage capacity. The comparison clearly indicates that it is far more cost effective to construct a new waste storage facility than it would be to upgrade the 2101-M Building to comply with RCRA requirements. A brief discussion of the cost comparison is included below.

\section{INITIAL DECONTAMINATION COSTS}

2101-M Building -- In utilizing the existing 2101-M Building, no decontamination costs were considered because there are no known areas within the building that are contaminated with either radioactive or non-asbestos hazardous materials. The removal of asbestos from the warehouse area of the 2101-M Building was estimated to cost $\$ 540,000$. If other contaminants are found during the upgrading work, an additional significant decontamination cost could be incurred.

New Facility -- A new storage facility would be constructed at the CWC. Initial decontamination is not a factor with a new facility.

\section{MODIFICATION AND UPGRADE COSTS}

2101-M Building -- The upgrading of the 2101-M Building to meet state and Federal requirements is estimated to cost $\$ 10,100,000$. The warehouse area upgrade costs were estimated separately from the office area to isolate the warehouse upgrade cost. The cost estimate assumes that buried systems such as water, sewer or electrical lines that may be under, or in the vicinity of the building will not have to be relocated.

\section{BUILD NEW FACILITY COST}

New Facilities -- The construction of a new $100,000 \mathrm{ft}^{2}$ facility is estimated to cost $\$ 5,038,000$. The new facility will be designed to meet the requirements of state and Federal codes, regulations, and requirements

\section{EVENTUAL D\&D OF EXISTING FACILITY COST}

2101-M Building -- If the 2101-M Building were upgraded and utilized for solid waste storage, the D\&D costs at the end of the mission are estimated to be $\$ 133,000$ or $\$ 1.33$ per $\mathrm{ft}^{2}$, in 1993 dollars. This cost for D\&D assumes that the building will not be contaminated with hazardous or radioactive materials during the use of the building.

New Facility -- If a new facility is constructed, the unused, existing facility will still require D\&D. Therefore, the cost of $\$ 133,000$ for $D \& D$ and $\$ 540,000$ for asbestos removal from the existing facility must be added to the cost of the new facility. 
WHC-EP-0636

TOTAL COST

2101-M Building -- The total cost to upgrade and utilize the warehouse area of the exjsting $2101-M$ Building is estimated to be $\$ 10,773,000$, or $\$ 107.73$ per $\mathrm{ft}^{2}$.

New Facility -- The total cost to construct a new warehouse facility for the storage of solid waste is estimated to be $\$ 5,844,000$, or $\$ 58.44 \mathrm{per} \mathrm{ft}^{2}$.

\subsection{SPECIFIC FACILITY EVALUATIONS}

The details and general conditions found in some of the facilities that were investigated are described in this section. Where applicable, the reasons why each particular building was not considered acceptable for upgrade to a storage facility are discussed.

\section{$6.12101-M, 200$ EAST AREA, OFFICE AND WAREHOUSE FACILITY}

The 2101-M was selected as the most suitable storage facility on the Hanford Site (from a cost standpoint) to provide temporary storage for solid mixed waste. 2101-M is a large warehouse complex located in the 200 East Area. The facility contains approximately $170,000 \mathrm{ft}^{2}$ of covered floor space, $100,000 \mathrm{ft}^{2}$ of which is warehouse area. The 2101-M Building is a structural steel framed one story building, covered with sheet metal roofing and siding.

The facility is currently utilized to store spare parts for a number of Hanford Site facilities including major equipment items for the Fuels Materials and Examination Facility (FMEF) Project that were never installed. The facility appears to be filled to approximately $95 \%$ of storage capacity and is not scheduled to be released for decommissioning until the year 2000 .

The field trip through the building gave the appearance the structure was in very good shape; however, after further investigation the building condition was found to be in relatively poor condition and major building modifications would be required before the building could be used to store the LLMW.

A number of electrically operated metal roll up doors are located throughout the facility to provide outside access, fire protection barriers, and area separation zones.

The floor loading for this facility is listed at 2,000 ibf/ $\mathrm{ft}^{2}$, which is adequate for RCRA storage; however, a replacement slab of adequate capacity with containment curbs, would be required because of a number of cracks in the 45 year old concrete siab. The cracked concrete floor must be removed and replaced to provide drainage and containment. 
A review of the WHC roof condition report indicates the sheet metal roof has deteriorated to the point that the roof is considered unsafe to walk on. The metal skin has corroded to the point that a pencil can be pushed through the metal (Figure 4). Roof leaks have been located during rain and snow storms.

A review of the Hanford Site asbestos assessment report indicates the cost of renovating this facility will include approximately $\$ 1$ million for removal and disposal of asbestos impregnated materials. Asbestos cement transit siding was used in this structure.

To evaluate the 2101-M upgrade, KEH estimated only $100,000 \mathrm{ft}^{2}$ of the building would be upgraded and these costs could be compared to the new construction costs for recently completed storage buildings. If the entire 2101-M Building were to be renovated, the actual costs to perform these building upgrades could in fact be 1.7 times the KEH estimate, since approval is not likely for the repair and upgrade of only a portion of the leaky roof, electrical, and HVAC systems.

\section{ANALYSIS OF 2101-M}

The renovation required to use this facility for the storage of the RCRA waste materials could be performed at a cost as listed in Table 3 .

The prime problem in planning to use this structure for storage is obtaining a release, upgrade, and permitting of this facility by 1997 . The facility is scheduled for release in fiscal year (FY) 2000 . The time required to move the materials currently stored there to other Hanford Site facilities and to perform the necessary construction required to qualify the structure for a RCRA storage facility would require a minimum of 1 year and possibly 18 months.

Where the materials currently being stored in this facility would be moved to, and who would pay for any necessary upgrades to the new storage facility would be additional issues to be resolved.

Based on the above unresolved issues this study concluded this structure would not be available to satisfy the scheduled WRAP storage needs.

\subsection{5-EA WAREHOUSE ESSENTIAL MATERIALS}

The 275-EA is an essential materials warehouse located north of Plutonium-Uranium Extraction (PUREX) in the 200 East Area. The wood frame warehouse contains an estimated $36,000 \mathrm{ft}^{2}$ of floor space, a large number of wood columns (approximately $25 \mathrm{ft}$ center lines) support the structure. The structure is approximately 45 years $01 d$. 
Figure 4. Building 2101-M Roof Deterioration.

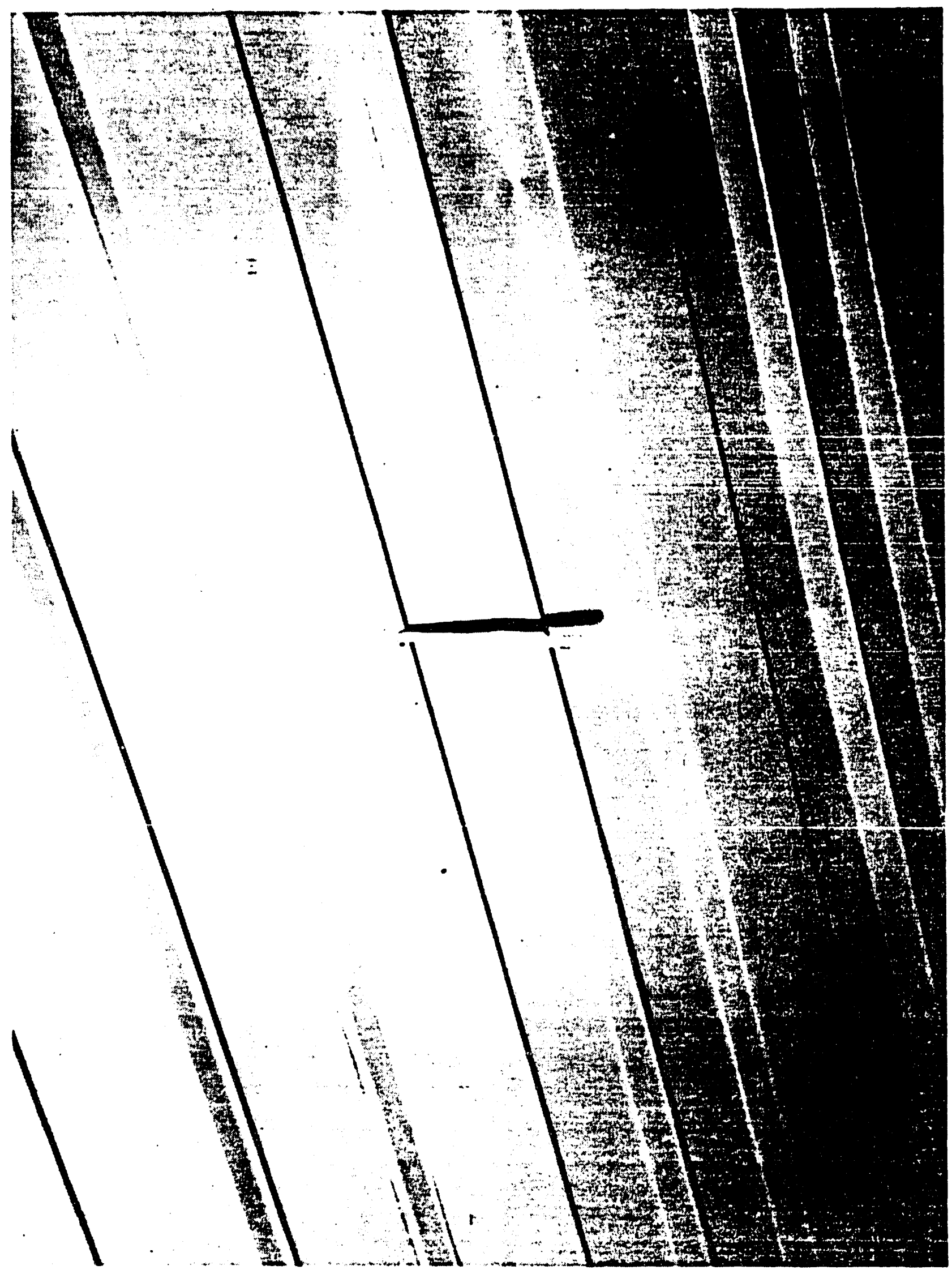


The roof is considered unsafe to walk on and is in need of repair. A large number of these wood columns that support the roof have been marked as needing replacement; however, because of funding restraints these repairs have not been completed.

The concrete floor is fragmented with cracks is rated at $2501 \mathrm{bf} / \mathrm{ft}^{2}$, which is not adequate for the projected waste material. The structure contains asbestos and is filled with spare parts, PUREX jumper hardware, and other miscellaneous hardware.

The structure is in need of many repairs and is currently considered an active and required facility with no scheduled date for its release from the active duty register.

\section{ANALYSIS OF 275-EA}

The renovation costs associated with upgrading this structure for use as a RCRA storage facility would exceed that of constructing a new warehouse to store this material. This study concluded this structure is not suitable for renovation and use as a RCRA storage facility because of the condition of the wooden structure and the concrete flooring.

\subsection{4-B CONCENTRATION FACILITY}

The 224-B Concentration Facility is a surplus building located in the 200 East Area. It js a reinforced concrete block structure containing an estimated $32,300 \mathrm{ft}^{2}$ of floor space. The structure consists of three floors plus an elevator motor house. The concrete block structure is in good condition, considering the structure is approximately 45 years old.

The first and second floors are 13 and 12-ft-high respectively, and the exterior dimensions are $60 \mathrm{ft}$ by $197 \mathrm{ft}$. The $14 \mathrm{ft}, 4-$ in.-high third floor is $60 \mathrm{ft}$ by $145 \mathrm{ft}$. A $27.4 \mathrm{ft}$ by $15 \mathrm{ft}$ by 14-ft-high elevator motor house for the cargo elevator sits on top of the third floor.

The building is divided along its length by a 1-ft-thick concrete wall that separates the contaminated process area from the non-contaminated office and operating area. The process area consists of six cells. One cell, a two story cell, is separated from all of the other cells except for process piping connections. The remaining five cells are three stories high and are separated from each other by 15-ft-high concrete block walls. There are ground floor and secondary story outside entrances to each of the five cells.

The process equipment and pipe are still in place in the contaminated cell area; this includes 42 tanks, 5 centrifuges, miscellaneous scales, pumps, motors, electrical power distribution, instrument control panels, and more than 15,000 linear $\mathrm{ft}$ of piping. Radiologically, there is an estimated 150 Curies ( $C i$ ) of plutonium contained in the cell area. Entry into any of these six cells requires the use of a respirator, but none of the cells have a significant dose rate.

Non-cell areas are essentially free of surface contamination, however, radioactive residue remains in some of the piping. 
WHC-EP-0636

\section{ANALYSIS OF 224-B BUILDING}

The old process structure is made up of a series of cells without interconnecting access. This type of structure would not be a suitable storage arrangement where forklift equipment is required to handle the drums and boxes:

The removal of the contaminated process equipment and the decontamination of the structure would be done by construction force account labor, wearing Special Work Procedure (SWP) clothing and using respirator equipment. The work in SWP clothing would also include the necessary modifications to the structure to comply with RCRA requirements. Work within a contaminated area where respirator equipment is required will reduce the productive labor to $50 \%$ of that experienced outside of contaminated zones. The cost of this cleanup/renovation work would require multimillion dollar up-front funding.

A large portion of the structure utilizes concrete block construction, which would not qualify as a seismically qualified containment structure. The HVAC duct contained within the structure is badly contaminated and would require extensive modifications to attain the required four air changes per hour to comply with RCRA storage requirements.

Normal remodeling projects that are located outside of any radiation zone usually costs twice that of new construction because remodeling requires the removal or replacement of many already installed pieces of equipment. Conclusions are that the cost of modifying the 224-B for RCRA storage is not practical and the building should not be considered as a possible candidate.

\subsection{4-T FACILITY}

The 224-T Facility, is located in 200 West Area, is similar to the 224-B Facility in the 200 East Area with the exception that the type of radioactive materials may differ slightly because the process missions for the two buildings were somewhat different. The 224-T Facility has been upgraded to meet seismic requirements.

The building is the location of the Transuranic Waste Storage and Assay Facility (TRUSAF), which only occupies the cold side of the building. Neutron assay and nondestructive examination equipment for TRU drums are in use in the building. The facility is a storage location for TRU waste until the WRAP Facility opens. This storage space for TRU waste drums is about $80 \%$ to $90 \%$ full. The upgradable condition of the hot side is not known at this time; however, efforts are underway to survey the hot side for possible future use.

The use of the 224-T Facility for the TRUSAF precludes its use for the storage of other types of solid waste. 


\subsection{1-EA AIRCRAFT HELICOPTER HANGAR}

The 2721-EA Aircraft Helicopter Hangar is relatively clean, has been constructed within the last 12 years, and is on the active facility list. The building has an area of $25,600 \mathrm{ft}^{2}$, but office space occupies part of the area. The structure is located in the 200 East Area and is used by the fire maintenance department to service Hanford Site fire fighting equipment.

The hangar is a single story metal frame structure with sheet metal roofing and siding. A large metal fold-up aircraft access door faces the south, which is approximately 100-ft-long and 15-ft-high. The sealing off of the large hangar door would be required for a RCRA storage facility.

The floor is in good condition and slopes to the southeast corner of the hanger, but the slope is so slight it tends to puddle and would require more slope and curbing for waste storage. The structure did not contain any posted floor loading information. The rated floor loading would require checking. Considering that the structure was designed for light aircraft service, extensive modifications to the floor could be required.

The roof is in good condition. There is no air handling equipment in the structure. The fire protection system is in good operating condition, although it was reported to have had three separate false occurrences that have activated the system over the past few years, completely flooding the building before it could be turned off.

A shipping and receiving area for truck off loading and access area would be required.

\section{ANALYSIS OF 2721-EA BUILDING}

The study concluded the remodeling costs involved in making the necessary modifications to this structure to comply with the RCRA requirements and the actual net floor space available when it was completed would result in excessive cost per usable square foot, resulting in this facility not being a suitable storage alternative. Another reason for disqualification of this structure is that it is currently on the active facility roster and is in use as a fire equipment maintenance shop.

\section{$6.6271-U$ OFFICE BUILDING}

The 271-U Office Building is located in the 200 West Area, adjacent and attached to the 221-U Canyon Building on the gallery side. The structure is $160 \mathrm{ft}$ by $48 \mathrm{ft}$ by $68 \mathrm{ft}$ with approximately $30,720 \mathrm{ft}^{2}$ of floor space. It is constructed of reinforced concrete foundation, floors, and pillars with concrete block walls and an asphalt and gravel roof. The concrete block exterior wall construction will not allow the structure to pass a seismic evaluation. 
The office building is a series of small rooms, each requiring modification, and provisions for material access. The basement contains compressors, ventilation supply equipment, offices, and shops. The first and second floor contain offices and storage. The third floor contains chemical makeup factlities and has an area that was previously used for plutonium storage.

The 296-U-10 Stack, which is mounted on the 271-U roof, exhausted the plutonium storage area. The contaminated HVAC duct would have to be modified to provide the required four air changes per hour.

The floor loading was not determined; however, an floor loading requirements for an office bullding is significantiy less than that of a storage facility capable of storing palleted 55 -gal drums, 3 drums high, where the drums could weigh $750 \mathrm{lb}$ each.

\section{ANALYSIS OF 271-U BUILDING}

Based on the above noted issues, the utilization of the 271- $U$ office Building as an alternate RCRA storage facility is not considered an economical alternative to constructing a new storage facility

\subsection{FUEL AND MATERIAL EXAMINATION FACILITY}

FMEF is a hot cell and fuel processing facility that contains approximately $216,846 \mathrm{ft}^{2}$ of floor space. The structure is located in the 400 Area.

The facility is constructed around a large hot cell with a number of smaller destructive examination cells in the lower floor. These cells have thick concrete shielding walls with steel liners and are equipped with shielding windows and manipulators. The cell areas have 1 imited access and are not suited for using a forklift for drum and box storage. The structure was designed with large corridors around the hot cells to support the remote examination activities the facility was originally designed for.

The corridors could be utilized as storage space; however, the need to inspect and retrieve any failed waste containers on a regular bas is would require forklift access in the corridor. This greatly reduces the usable storage space.

The area above the large hot cell is equipped for Fast Flux Test Facility (FFTF) fuel fabrication and contains the Secure Automated Fabrication (SAF) equipment lines.

The facility is radiation free and there are several planned future missions for this facility. The facility is not on the Hanford Surplus Facility Listing and there is no published release date denoting when this facility will be placed on the surplus list. Process type structures containing individual cells and heavy shielding walls, would require major remodeling to provide access for the movement and storage of waste materials; therefore, this type of structure is generally not suited for waste storage. 


\section{ANALYSIS OF 427 BUILDING}

The facility is currently on the active facility list and not released for storage needs. In addition, this process type structure is not well suited for forklift access and drum handling or storage requirements.

Therefore, the 427 FMEF Facility is not considered a suitable facility for the storage of the LLMW.

\subsection{MAINTENANCE AND STORAGE FACILITY}

The Maintenance and Storage Facility (MASF) is a 60,197 $\mathrm{ft}^{2}$ facility located in the 400 Area. The facility is currently a support maintenance facility for the FFTF Reactor and it is scheduled to be utilized as a facility to prepare the FFTF fuel for storage/disposal when the reactor is shut down.

Based on the current mission scheduled for this facility it will not be available for use as a waste storage facility.

\section{$6.922 \mathrm{j}-\mathrm{U}$ PLANT CANYON BUILDING}

The 221-U Plant Canyon Butlding is a $83,500 \mathrm{ft}^{2}$ building located in the 200 West Area. The building is $810 \mathrm{ft}$ by $66 \mathrm{ft}$ and $77-\mathrm{ft}-\mathrm{tall}$, and consists of 20, 40-ft-long process cells that are divided by reinforced concrete sections separated by expansion joints. A wall ranging in thickness from $5 \mathrm{ft}$ to $9 \mathrm{ft}$, divides the building along its length into a process side and a gallery side.

A large 24-in. diameter, concrete encased clay tile radioactive drain pipe, located below the cells, provided drainage for all the cells to a sump located in cell 10. This main drain pipe is approximately $45 \mathrm{ft}$ below grade, has cracks in it, and contains high levels of radioactive materials.

The gallery side of the building has four floors and each floor has a gallery that is 14-ft-wide (inside dimension). From the top floor down, these are: crane gallery, operating gallery, pipe gallery, and electrical gallery, respectively. These galleries contain all the piping, instrumentation control and electrical distribution equipment required to remotely operate the in-cell process equipment.

The contaminated gallery and in-cell equipment is still installed and would require decommisstoning.

\section{ANALYSIS OF 221-U BUILDING}

Based on an 8 year old study by Rockwell International titled, "Long Range Decommissioning Plan for Rockwell Hanford Operations Surplus Facility Management Program," the up-front cost to decommission this facility was estimated at $\$ 27,000,000$ or $\$ 323$ per $\mathrm{ft}^{2}$. The cost to modify the facility to comply with RCRA, Safety, and Environmental Requirements would add additional upgrade costs to the facility. 
These estimates were further substantiated with an engineering study prepared by KEH t1tled, "Hanford Waste Vitrification Plant Interim Storage Facility for Hanford Waste Vitrification Plant Evaluation of Alternates," prepared in June 1990. This study concluded it would cost over $\$ 20$ milition to use efther the 221-U or the PUREX Facility for an alternate storage facility.

Based on the reasons listed above, this facility is not considered suitable as a temporary waste storage facility.

\subsection{1-B, 221-T, PLUTONIUN URANIUN EXTRACTION PLANT, AND REDUCTION OXIDATION PLANT}

The 221-B, 221-T, PUREX, AND Reduction Oxidation (REDOX) P1 ant are canyon type buildings similar to the 221-U Building discussed above. Based on the reasoning and cost estimates discussed Section 6.9 above, this study concluded that decontamination and upgrade of any of these buildings, some of which contain higher levels of contamination than the 221-U Building, are not economicaliy viable alternatives to be considered for upgrading to a solid waste storage facility.

\subsection{1-2 MATERIAL ENGINEERING LABORATORY}

The 231-Z Material Engineering Laboratory is located at $Z$ Area in the 200 West Area, and is a two story process facility containing $54,000 \mathrm{ft}^{2}$ of floor space. The facility was constructed in 1944 as part of the original Manhattan Project and is approximately 48 years old.

The original bullding structure was constructed using concrete pillars filled with concrete block. The structure is currently in use for offices, craft shops, training, and waste storage. WHC and Pacific Northwest Laboratories (PNL) currently share the building. PNL has their portion of the building filled with contaminated glove boxes and 55-gal drums of radioactive waste materials.

Access to the upper floor is via two stairwells; however, no elevators are avallable for material handling capabilities for the second floor. The lower process area contains four (shielded) hot cells containing contaminated piping and equipment. Contaminated piping systems are also located on the second floor.

The facility is currently serviced with 200 West Area water, steam, electrical, and telephone services and has an operational fire detection and protection system. The HVAC system is operational al though it is contaminated with TRU and, if used for any extended service, spare parts and maintenance would likely become a serious problem.

The roof contains asbestos impregnated material, currently has many leaks but is considered safe to walk on. Asbestos is currently installed as pipe insulation and is also used in the floor tile throughout the facility. 
WHC-EP-0636

\section{ANALYSIS OF 231-Z BUILDING}

The cost to remove the contaminated process equipment, decontaminate the structure, replace the roof, remove the hazardous asbestos materials contained throughout the facility and make the modifications necessary to comply with RCRA requirements would greatly exceed the cost of constructing a new storage facility. The concrete filler blocks between the concrete pillars will not meet seismic qualification requirements for the site.

Based on the issues listed above and their associated costs, this study concluded the 221-2 Facility is not suitable as a RCRA storage facility.

\subsection{2-A, 4732-B, AND 4732-C FAST FLUX TEST FACILITY WAREHOUSES}

The 4732-A, B, and $C$ warehouses have a combined floor space of $59,000 \mathrm{ft}^{2}$. They are located at the FFTF site within the 400 Area. These facilities are currently filled with FFTF spare parts and equipment.

The bulldings were constructed in the 1970's and 1980's, and are structural steel framed metal bulldings that are in good condition and do not contain any contamination. However, the structures do not contain the required RCRA containment curbs, drainage, and sumps.

These buildings are located near the FFTF office buildings that house a large number of engineering and management personnel.

\section{ANALYSIS OF 4732A, 4732B, AND 4732C BUILDINGS}

The scheduled release of these warehouse structures from FFTF support, for other program activities, will preclude the use of these facilities in the 1997 time frame. Also, the buffer zone requirements governing higher activity LLMW waste storage in relation to the physical location of office personnel located in the FFTF Office Building Complex would present as low as reasonable achievable (ALARA) and safety concerns, further precluding the use of these facilities in the 1997 time frame.

Based on the issues discussed above, these warehouse facilities will not be avallable within the time frame required to support the storage requirements and, therefore, cannot be considered.

\subsection{REFERENCES}

40 CFR 260, 1992, "Hazardous Waste Management System - General," Code of Federal Regulations, as amended.

40 CFR 261, 1992, "Identification and Listing of Hazardous Waste," Code of Federal Regulations, as amended. 
40 CFR 262, 1992, "Standards Applicable to Transporters of Hazardous Waste," Code of Federal Regulations, as amended.

40 CFR 263, 1992, "Standards Applicable to Transporters of Hazardous Waste," Code of Federal Regulations, as amended.

40 CFR 264, 1992 "Standards for Owners and Operators of Hazardous Waste Treatment, Storage, and Disposal Facilities," Code of Federal Regulations, as amended.

40 CFR 265, 1992, "Interim Status Standards for Owners and Operators of Hazardous Waste Treatment, Storage, and Disposal Facilities," Code of Federal Regulations, as amended.

40 CFR 266, 1992, "Standards for the Management of Specific Hazardous Wastes and Specific Hazardous Waste Management Facilities," Code of Federal Regulations, as amended.

40 CFR 267, 1992, "Interim Standards for Owners and Operators of New Hazardous Waste Land Disposal Facilities," Code of Federal Regulations, as amended.

40 CFR 268, 1992, "Land Disposal Restrictions," Code of Federal Regulations, as amended.

40 CFR 270, 1992, "EPA Administered Permit Programs: The Hazardous Waste Permit Program," Code of Federal Regulations, as amended.

Atomic Energy Act, 1954, 42 USC 2011 et seq.

DOE, 1988, General Environmental Protection Program, DOE Order 5400.1, U.S. Department of Energy, Washington, D.C.

DOE, 1989, General Design Criteria, DOE Order 6430.1A, U.S. Department of Energy, Washington, D.C.

DOE-RL, 1991, Hanford Central Waste Complex - Radioactive Mixed Waste Storage Facility Dangerous Waste Permit Application, 2 Vols., D0E/RL-91-0017, U.S. Department of Energy, Richland Operations Office, Richland, Washington.

Resource Conservation and Recovery Act of 1976, 42 USC 6901 et seq.

State Environmental Policy Act, RCWA 43.21C010 et seq.

Ecology, EPA, and DOE, 1990, Hanford Federal Facility Agreement and Consent Order, 2 vols., as amended, Washington State Department of Ecology, U.S. Environmental Protection Agency, and U.S. Department of Energy, Olympia, Washington.

Daly, K.S. and H.B. Hathaway, 1993, Harford Integrated Office Space Plan, WHC-EF-LL-SD-033, West inghouse Hanford Company, Richland, Washington.

WAC 173-303, 1990, "Dangerous Waste Regulations," Washington Administrative Code, as amended. 


\section{WHC-EP-0636}

Wells, G.T. and M.C. Hughes, 1990, Hanford Site Asbestos Abatement Plan, WHC-EP-0390, Westinghouse Hanford Company, Richland, Washington.

WHC, 1992, Environmental Compliance, WHC-CM-7-5, Westinghouse Hanford Company, Richiand, Washington.

KEH, 1990, Engineering Study, "Hanford Waste Vitrification Plant Project Interim Storage Facility for Hanford Waste Vitrification Plant Canisters, Evaluation of Alternatives," ER0665ES, Kaiser Engineers Hanford Company, Richland, Washington. 
WHC-EP-0636

APPENDIX A

2101-H UPGRADE ESTIMATE

A-1 


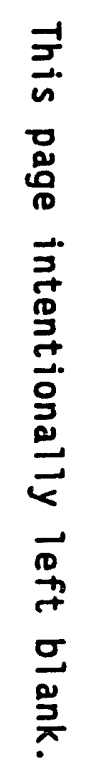


KAISER ENGINEERS HANFORD WESIINGHOUSE HAMFORD COMPANY JOB NO. BLOG $2101 M$
FILE NO. BLOZIOIM ALIERHATIYE SOLIO HASIE SIORAGE SIUDY DOE_ROI - PROJECT COSI SUMMARY
PAGE 1 OF 8

DATE $12 / 18 / 9211: 20: 11$

BY GPM

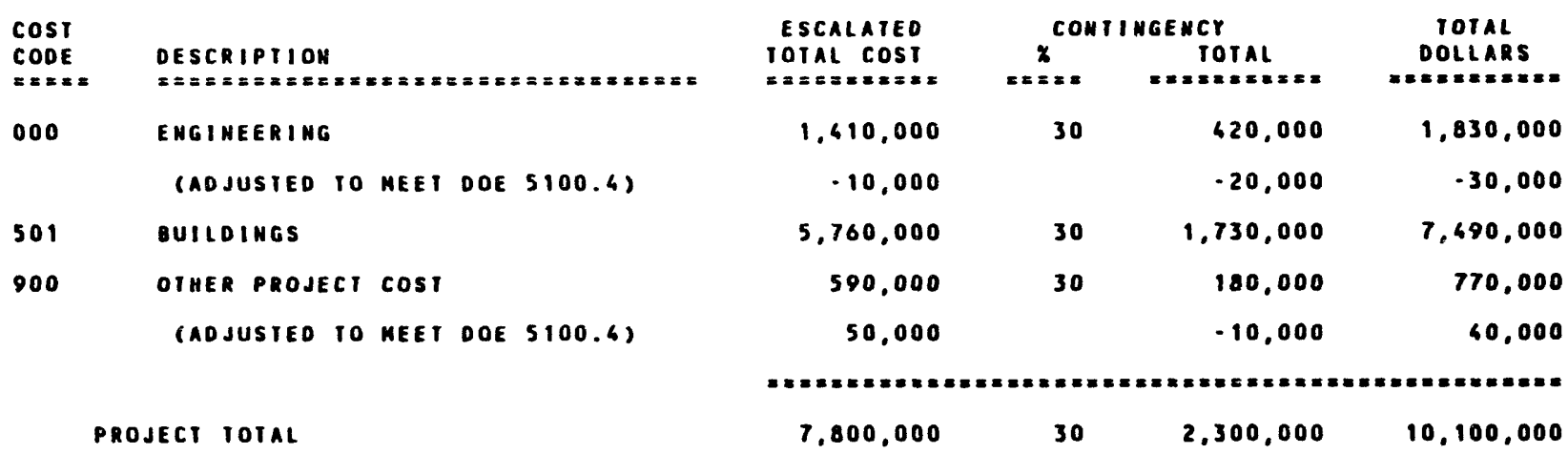

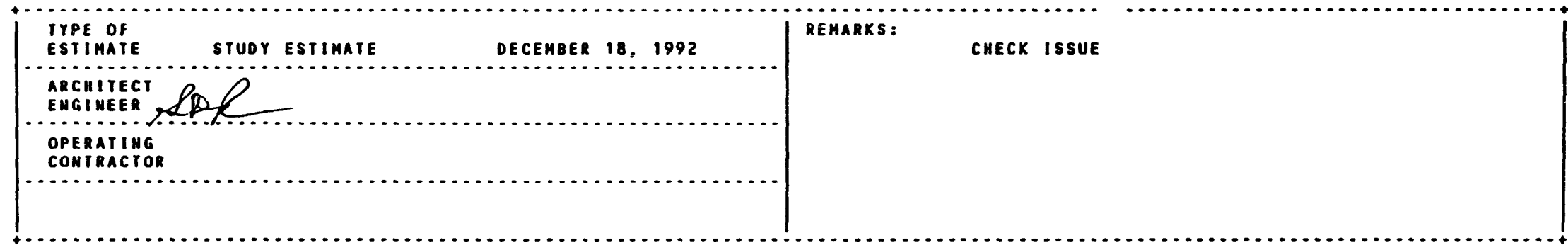

(ROUHOED/ADJUSTED TO THE MEAREST "10,000, 100,000" PERCEMTAGES hOT RECALCULATED tO REFLECT ROUHDIMG) 


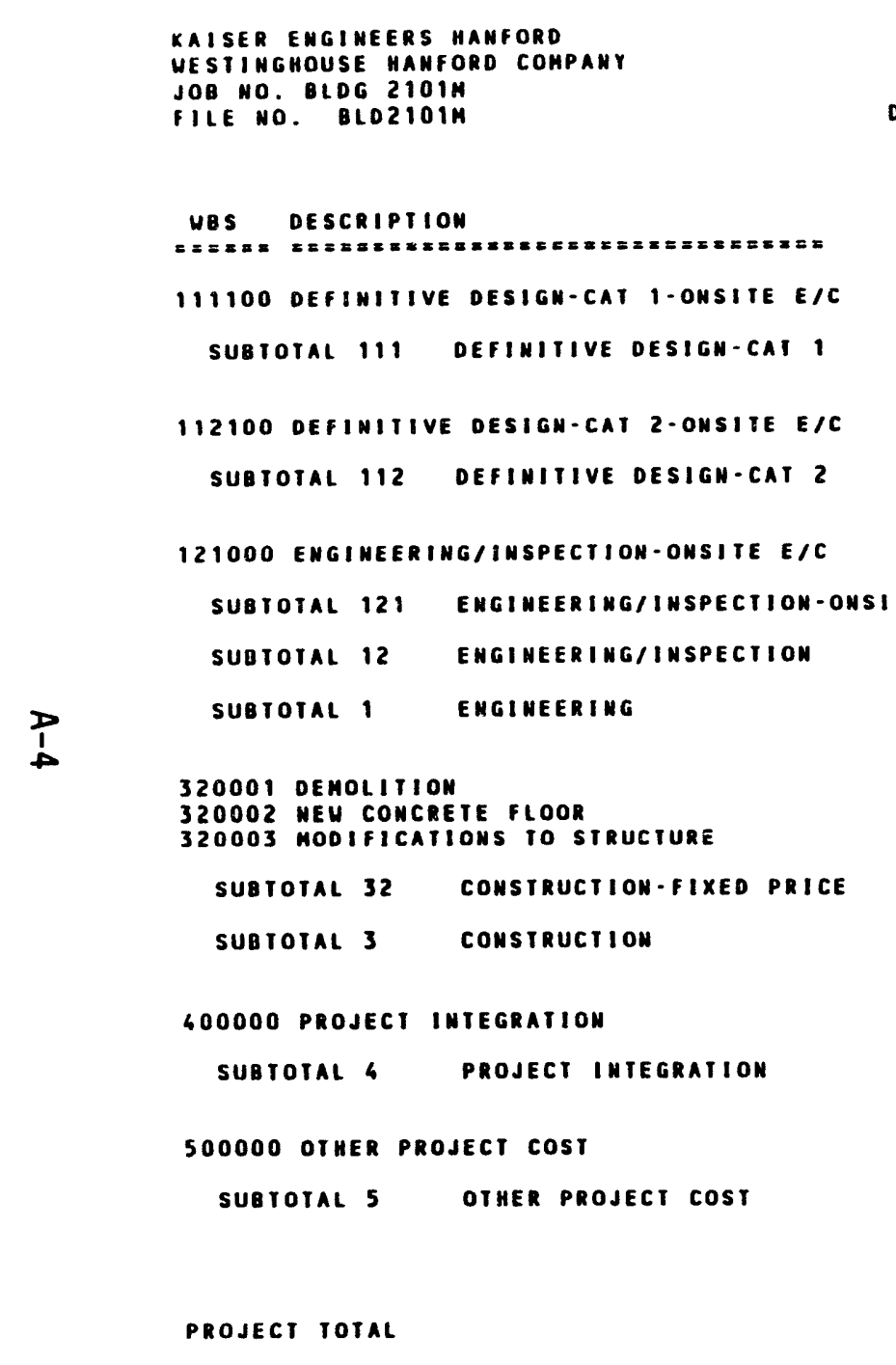

* iest - interactive estimating -.

AL IERHATIVE SOLIO WASTE STORAGE STUDY

$\begin{array}{llll}\text { PAGE } & \text { OF } & 8 \\ \text { DAIE } & 12,18 / 92 & 11: 20: 15\end{array}$

DOE_ROZ - WORK BREAKDOWH SIRUCIURE SUMHARY

\begin{tabular}{|c|c|c|c|c|c|c|c|c|}
\hline $\begin{array}{l}\text { ESI IMAIE } \\
\text { SUB IOIAL } \\
==x=x==\end{array}$ & $\begin{array}{l}\text { ONSIIEE } \\
\text { I WDIRECIS } \\
=x== \pm=x=x\end{array}$ & $\begin{array}{c}\text { SUB } \\
\operatorname{loTAL} \\
=x=x=x=x\end{array}$ & $\begin{array}{l}\text { ESCA } \\
x \\
=x=x=\end{array}$ & $\begin{array}{l}L A T I O M \\
\text { TOTAL } \\
=x=x==x=2\end{array}$ & $\begin{array}{c}\text { SUB } \\
\text { IOTAL } \\
x=x=x=x\end{array}$ & $\underset{x}{\operatorname{con} 1}$ & $\begin{array}{l}\text { NGENCY } \\
\text { TOTAL } \\
=x=x=x=20 x\end{array}$ & $\begin{array}{c}\text { TOIAL } \\
\text { DOLLARS } \\
=x=x=x=x=\end{array}$ \\
\hline 237000 & 0 & 237000 & 16.92 & 40100 & 277100 & 30 & 83130 & 360231 \\
\hline 237000 & o & 237000 & 16.92 & 40100 & 277100 & 30 & 83130 & 360231 \\
\hline 592503 & 0 & 592503 & 16.92 & 100252 & 692755 & 30 & 207826 & 900581 \\
\hline 592503 & 0 & 592503 & 16.92 & 100252 & 692755 & 30 & 207826 & 900581 \\
\hline 355502 & 0 & 355502 & 23.54 & 83685 & 439187 & 30 & 131756 & 570943 \\
\hline 355502 & 0 & 355502 & 23.56 & 83685 & 439187 & 30 & 131756 & 570943 \\
\hline 355502 & 0 & 355502 & 23.54 & 83685 & 439187 & 30 & 131756 & 570943 \\
\hline 1185005 & 0 & 1185005 & 18.91 & 224037 & 1409062 & 30 & 422712 & 1831755 \\
\hline $\begin{array}{r}635752 \\
923261 \\
2391006\end{array}$ & $\begin{array}{l}108078 \\
2111954 \\
606472\end{array}$ & $\begin{array}{r}763830 \\
1135215 \\
2797678\end{array}$ & $\begin{array}{l}18.22 \\
18.22 \\
18.22\end{array}$ & $\begin{array}{l}135526 \\
206837 \\
509700\end{array}$ & $\begin{array}{r}879356 \\
1362051 \\
3307176\end{array}$ & $\begin{array}{l}30 \\
30 \\
30\end{array}$ & $\begin{array}{l}263807 \\
602616 \\
992153 .\end{array}$ & $\begin{array}{l}1143162 \\
1744667 \\
6299331\end{array}$ \\
\hline 3950019 & 726506 & 4676523 & 18.22 & 852063 & 5528583 & 30 & 1658576 & 7187160 \\
\hline 3950019 & 726504 & 4676523 & 18.22 & 852063 & 5528583 & 30 & 1658576 & 7187160 \\
\hline 197501 & 0 & 197501 & 18.22 & 35985 & 233486 & 30 & 70046 & 303531 \\
\hline 197501 & 0 & 197501 & 18.22 & 35985 & 233486 & 30 & 70046 & 303531 \\
\hline 500000 & 0 & 500000 & 18.22 & 91100 & 591100 & 30 & 177330 & 768430 \\
\hline 500000 & 0 & 500000 & 18.22 & 91100 & 591100 & 30 & 177330 & 768430 \\
\hline 832,525 & & 559.029 & 18.34 & & $7,762.211$ & 30 & & $10,090,876$ \\
\hline
\end{tabular}


KAISER EMGINEERS MANFORD

WESTINGHOUSE MAMFC

$J O B$ MO. BLOG 2 TOIH

1. DOCUMENTS AND DRANINGS

$== \pm= \pm=2=2$

DOCUMENTS: MONE

DRAHIMGS: SKEICH OF FLOOR PLAN

2. MATERIAL PRICES

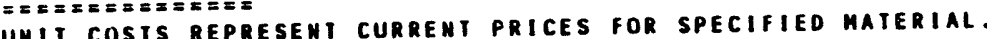

3. LABOR RATES

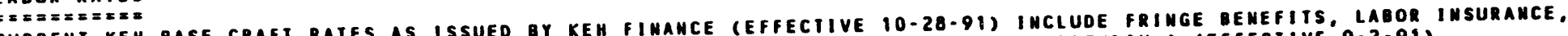

TRAVEL WHERE APPLICABLE. PER HAHFORD S!TE STABILIZAIION AGREEHEMT APPEND ISUED BY KEH FIMAMCE (EFFECTIVE

$10-28-91)$.
$10-21$ HOU

4. GENERAL REQUIREMEMTS/TECHMICAL SERVICES

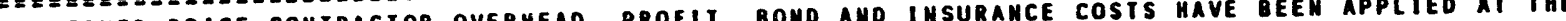

A.) FIXED PRICE CONTRACTOR OVERHEAD. PROFIT. BONO ANO THSURANC CO COLUHA OF THE ESTIMATE DETAIL:

FOLLOUING PERCENTAGES 25 . AND IOX SUBCOHIRACIS.

5. ESCALATION

Es = Ea

6. ROUHOING - LINE ITEMS

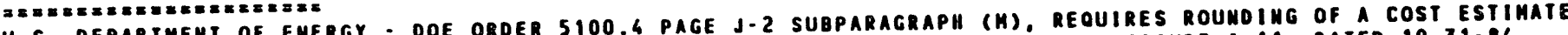

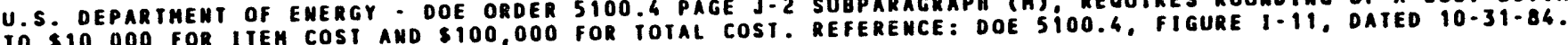

7. REMARKS

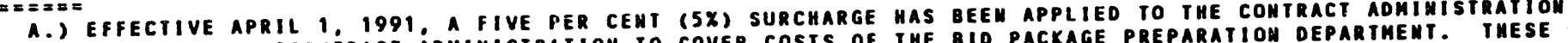
EFFECIIVE APRIL 1. FACTOR FOR SUBCONTRACT AOHINIVE PER POS REPORT (DOE ROT)

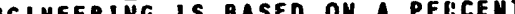

B.) THE ENGINEERIHG TS BASEO ON A PETCENTACE OF COMSTRUCTrON COST AND REPI

D.) ESCALATIOH IS BASED OM ASSUMED START DATES.

D. J ESCORT COST HAS MOT BEEM INCLUDED IF REQUIRED.

F. THIS ESTIMATE ASSUMES COUSTRUCYIOU UILL OE BY A FIXED PRICE CONTRACTOR.

THIS ESTMATE DOES WOT IMCLUDE COST FOR AHY UTILITIES THAT MAY BE REOUIRED FOR MODIFYIMG THE STRUCTURE.

ACIIIY THAT HAS A TOTAL SOFT OF APPROX. HIS EXISTING PROJECT IS TO MODIFY 100,000 SOFT OF AN EXISTING FACIITY TAT HAS A TOTAL SOF ORPACD OY IHE MODIFICATIONS TO THE WASTE STORAGE AREA. 


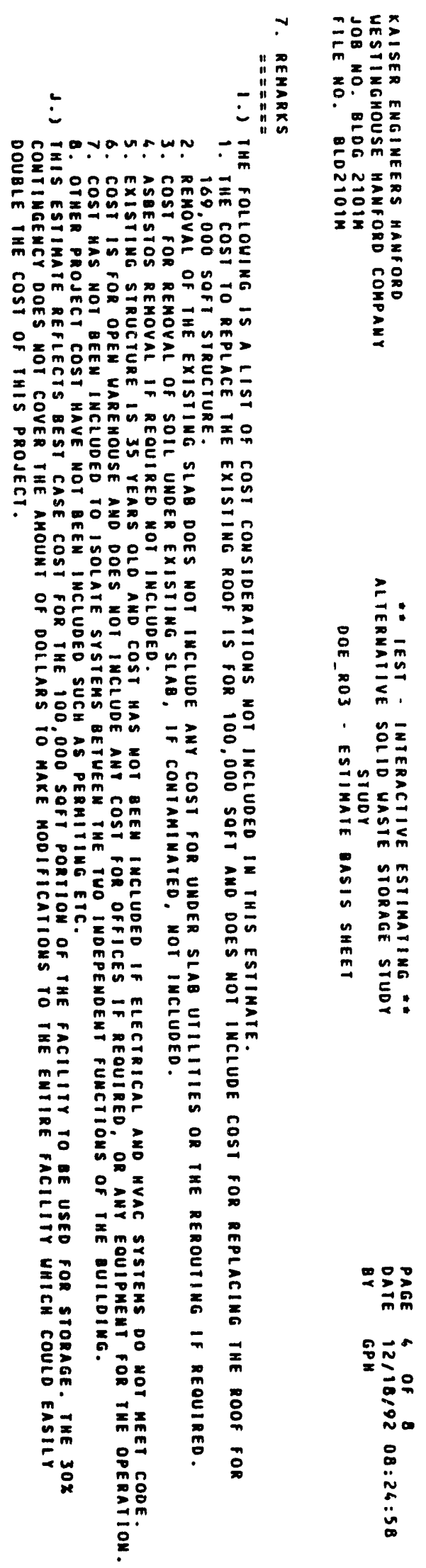


KAISER ENGINEERS HAMFORD

WESIINGHOUSE HANFORO COMPAMY

JOB HO. BLDG $2101 \mathrm{H}$

$\cos 1$

CODE/WOS

DESCRIPTION

OOO ENGINEERIMG

111100 DEFINITIVE DESIGN-CAT 1-ONSIJE E/C 112100 DEFINITIVE DESIGN-CAI 2-ONSITE E/C

IOIAL 000 EMGIMEERING

SOI BUILDINGS

$\stackrel{7}{1}$

320001 DEMOLITION

MEW CONCRETE FlOOR

320003 MODIFICATIONS TO STRUCTURE

400000 PROJECT IMTEGRATION

TOIAL 501 BUILDIMGS

900 OTHER PROJECT COST

500000 OTHER PROJECT COST

TOTAL 900 OTHER PROJECT COSI

PROJECT TOTAL

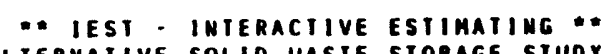

DOE ROA - COST CODE ACCOUNT SUMMARY

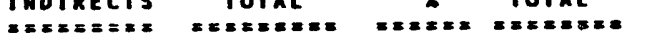
$\operatorname{TOTAL}_{x= \pm x= \pm}$

$x$ TOTAL

$\begin{array}{ll}\text { PAGE } & 5 \text { OF } 8 \\ \text { DAIE } & 12 / 18 / 92 \quad 11: 20: 18\end{array}$

BY GP

237000
592503

592503
355502

$0 \quad 237000$

$237000 \quad 16.92=40100$

$\begin{array}{rr}16.92 & 40100 \\ 16.92 & 100252 \\ 23.54 & 83685\end{array}$

277100
692755
439187

30
30
30

$83130 \quad 360231$

1185005

01185005

18.91

226037

1609062

30

$\$ 22712$

570943

1831755

\section{2}

923261

108078
211954

2

2391006
197501

1135215

6147520

726506

2797678
197501

18.22
13.22

206837

6.22 509700

$18.22 \quad 35985$

6876026

18.22

888048

879356
1342051
3307176
233486

30
30
30
30

$5762089 \quad 30$

402616

1728622

764667

289331

303531

7490691

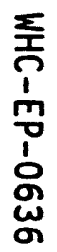

500000

- $\quad 500000$

18.2291100

591100

30

177330

768430

500000

o 500000

18.2291100

591100

177330

768630

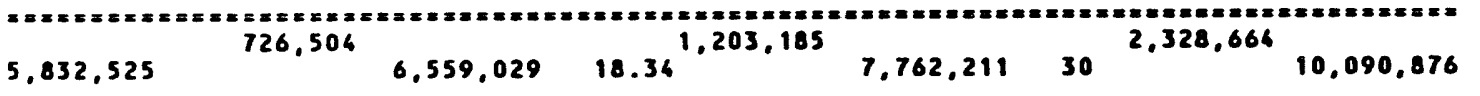


KAISER ENGINEERS HAMFORD YESTIMGHOUSE HAMFORD COMPANY

JOB MO. BLDG 2101 H

CSI DESCRIPTIOI

ENGINEERING

DO TECHMICAL SERVICES

TOTAL EMGINEERING

$\stackrel{7}{1}$

\section{CONSTRUCTION}

OO
TECHNICAL SERVICES
02 SIIEHORK
03 COMCREIE
O5 HETALS
07 MOISTURE AND THERHAL
09 FIMISHES
15 MECHANICAL
16 ELECIRICAL

16 ELECIRICAL

TOTAL CONSTRUCTION

PROJECT TOTAL
- IEST - interactive estimatimg aLterMatiVE SOLID UASIE STORAGE SIUDY DOE_ROS - ESIIMATE SUMAARY OY CSI DIVISION
PAGE 6 OF 800 PATE $12 / 18 / 92 \quad 11: 20: 21$

DAY GPM

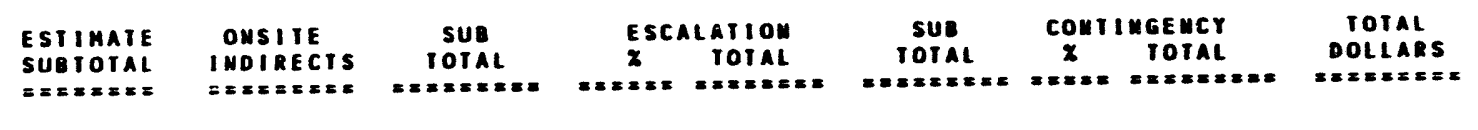

$\begin{array}{rrrrrrrrr}1185005 & 0 & 1185005 & 18.91 & 224037 & 1609042 & 30 & 622712 & 1831755 \\ 1.185 .005 & 0 & & & 226.037 & & & 622.712 & \\ & & 1.185 .005 & 18.91 & & 1.409 .042 & 30 & & 1.831 .755\end{array}$

$1.185,005$

$1,105,005$

\section{5}

697501
635752
486216
238063
384450
390538
110000
715000

108078
137657
60471
65357
66391
187000
121550

$\begin{array}{ll}697501 & 18.22 \\ 743830 & 18.22\end{array}$

$\begin{array}{lll}623830 & 18.22 & 135526 \\ 623873 & 18.22 & 113670\end{array}$

$\begin{array}{rrr}623873 & 18.22 & 113670 \\ 278534 & 18.22 & 50769\end{array}$

$46980718.22 \quad 81955$

$656920 \quad 18.22 \quad 83253$

$18.22 \quad 23649$

234491
152419

826586
879356

879356
737542

531761

491

988969

979.148

$5,374.024 \quad 18.22$

6.353 .169

$30 \quad 247376$

$30 \quad 263807$

221263

98785
159528

16205

45664

296691

1071961

1163162

428067

691290

702237

1977939

285660

4.667 .520

726,504

$6,559.029 \quad 18.34$

$1,203,185$

$7,762,211$

30

$2,328,664$

e.259.121

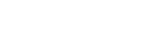


KAISER EMGINEERS HAMFORD

WESTIMGHOUSE HANFORD COMPAM

JOB MO. BLOG $2101 \mathrm{M}$

HIE MO. BL2101M
- IEST - IHIERACIIVE ESIIMATIMG ALTERMATIVE SOLIO HASIE STORAGE STUDY DOE_ROG - COMTIMGEMCY AMALYSIS EASIS SMEET
PAGE T OF 8
OATE I11/20/92 OQ:25:08
OY GPW

$\begin{array}{lll}\text { REFEREMCE: ESTIMAIE EASIS SHEEI } & \text { PAGE } 384 \text { OF } 8 \\ \text { COSI CODE ACCOUMI SUMMARY } & \text { PAGE } 5 \text { OF } 8\end{array}$

THE U.S. DEPARTMEMT OF EMERGY - RICMLAMD ORDER 5700.3 -COSTESTIMATIMG. AMALYSIS AMO STAMOARDIZATIONE DAIED 3-27-85. PROVIDES GUIDELIMES FOR ESTIMAIE CONTIUGE WCIES. TME GUIDELIHE FOR A SIUDY ESTIMATE

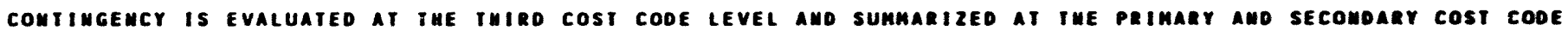
LEVEL OF THE DETAILED COST ESTIMATE.

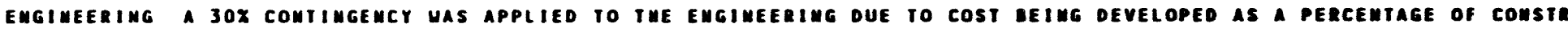

AVERAGE EHGIMEERIMG CONIIMGEMCY

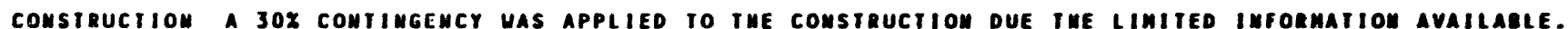

AVERAGE COMSIRUCTION COMTIMGEMCY $30 x$ 


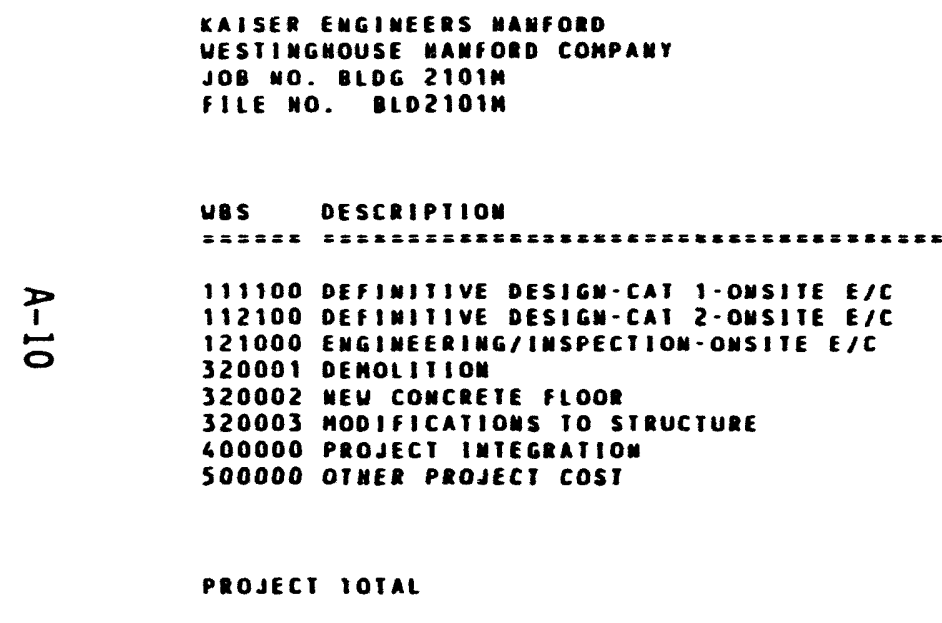

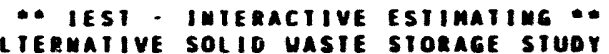

DOE_Ro - OUSITE IMDIRECT cosis eY ues $\begin{array}{ll}\text { PACE } & \text { OF } \\ \text { OAIE } 12,118 / 92 \quad 11: 20: 26\end{array}$

\begin{tabular}{|c|c|c|c|c|c|}
\hline $\begin{array}{l}\text { ESIIMATE } \\
\text { SUEIOTAL } \\
===x==x=\end{array}$ & 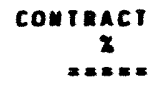 & $\begin{array}{c}\text { AOMIMISIRATIOU } \\
\text { TOIAL } \\
==x=x==x=\end{array}$ & $\begin{array}{l}\text { ID PACK } \\
\text { PREP. } \\
\text { =E=EX:E= }\end{array}$ & 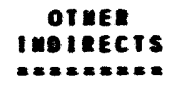 & 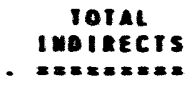 \\
\hline $\begin{array}{r}237000 \\
592503 \\
355502 \\
635752 \\
923261 \\
2391006 \\
197501 \\
500000\end{array}$ & $\begin{array}{r}0.00 \\
0.00 \\
0.00 \\
17.00 \\
17.00 \\
17.00 \\
0.00 \\
0.00\end{array}$ & $\begin{array}{r}0 \\
0 \\
0 \\
108078 \\
156956 \\
406672 \\
0 \\
0\end{array}$ & $\begin{array}{r}0 \\
0 \\
0 \\
0 \\
15000 \\
0 \\
0 \\
0\end{array}$ & $\begin{array}{r}: \\
: \\
0 \\
00000 \\
: \\
0 \\
0\end{array}$ & $\begin{array}{r}0 \\
0 \\
108078 \\
2111956 \\
606472 \\
0 \\
0\end{array}$ \\
\hline
\end{tabular}

15,000

726.506

5.832 .525
60,000 


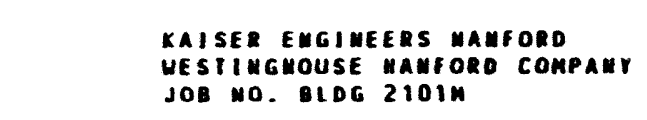

WESIIMGMOUSE MAMFORO COMPAMI

JOB NO. BIDG $2101 M$

account

MUMBER DESCRIPIION

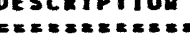

DEFINITIVE DESIGN-Cat 1-ONSITE E/C

P $\quad 111100.00$

DEFIIIIIIVE OESIGA CAI

$6 x$ consi. cosi

SUETOIAL IECMMICAL SERVICES

rotal

COST CODE 00000

(ESCALAiIOX $16.92 \times$ - COMIIMGENCY $30.00 x$ )

rotal was 111100 defINITIVE DESIGK-CAT 1-OMSITE E/C

000

altermative SOLIO WASTE STORAGE SIUDY

DOE_ROB - ESTIMATE OEIAIL or ues / COSI CODE
* IESI - InIERACIIVE ESIIMATIMG -

PAGE
OAYE $12118 / 92 \quad 11: 20: 27$

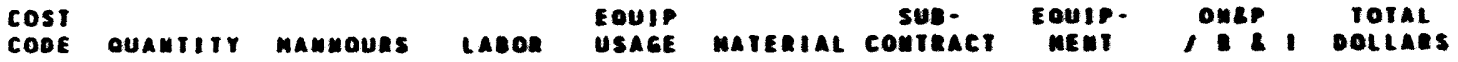

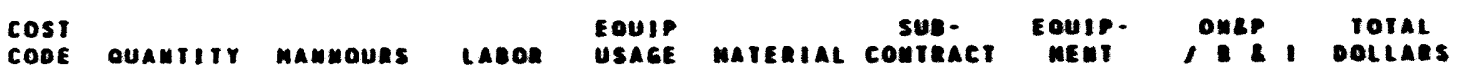

(1)

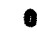

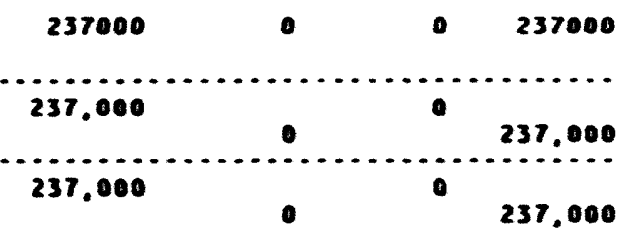

$237.000 \quad 0 \quad 237,000$


KAISER EMGIMEERS WAWFORD

WESTIWGHOUSE WharroRo COMPAMY

JOB WO. BLO 21011

account

MUMBER

\section{DESCRIPIION}

$= \pm x=x=x=x=x=$

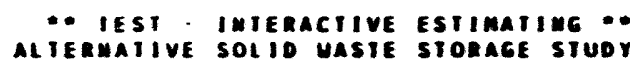

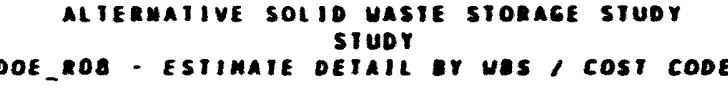

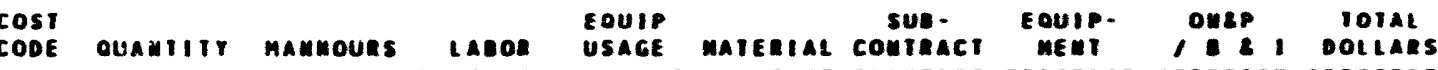

112100 Definitive ofsign-cat z-OMSITE EIC

$\frac{1}{1}$

112100.00 TECWMICAL SERVICES

112100.0000002 DEFIMITIVE DESIGH CAI 2
15X COHST. COST

000

$\begin{array}{cc}0 & 0\end{array}$

0

- 592503

PAGE
DAIE $12,18 / 92 \quad 11: 20: 27$
OY GPW

SUBJotal TECMUICAL SERVICES

10:AL

COS 1 CODE 00000

(ESCALATION $16.92 \times$ - COMIINGENCY $30.00 x$ )

i is
$\cdots \ldots \ldots \ldots$

0

592.503

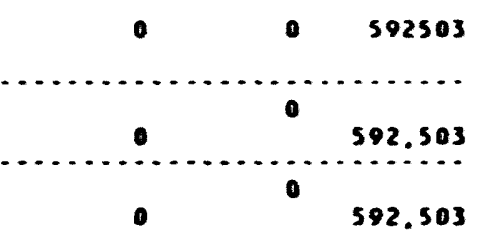

$\begin{array}{lll}592.503 & 0 & 592.503\end{array}$

TOIAL WES 112100 DEFINITIVE DESIGM-CAT 2-ONSITE E/C

(1)

○

(

592.503

-

592.503 


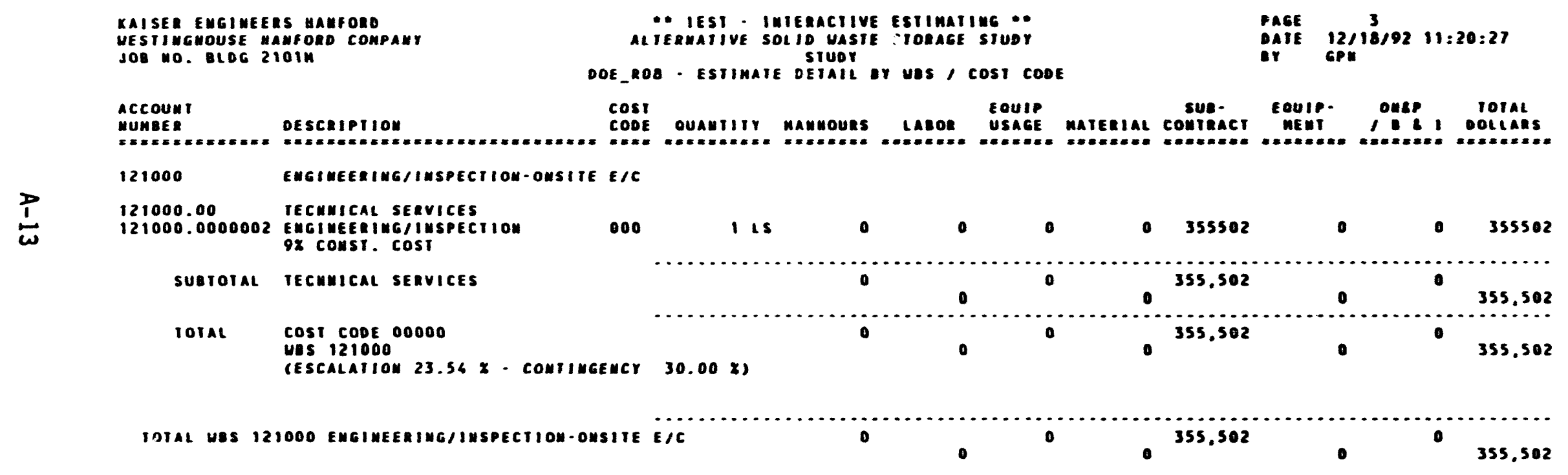




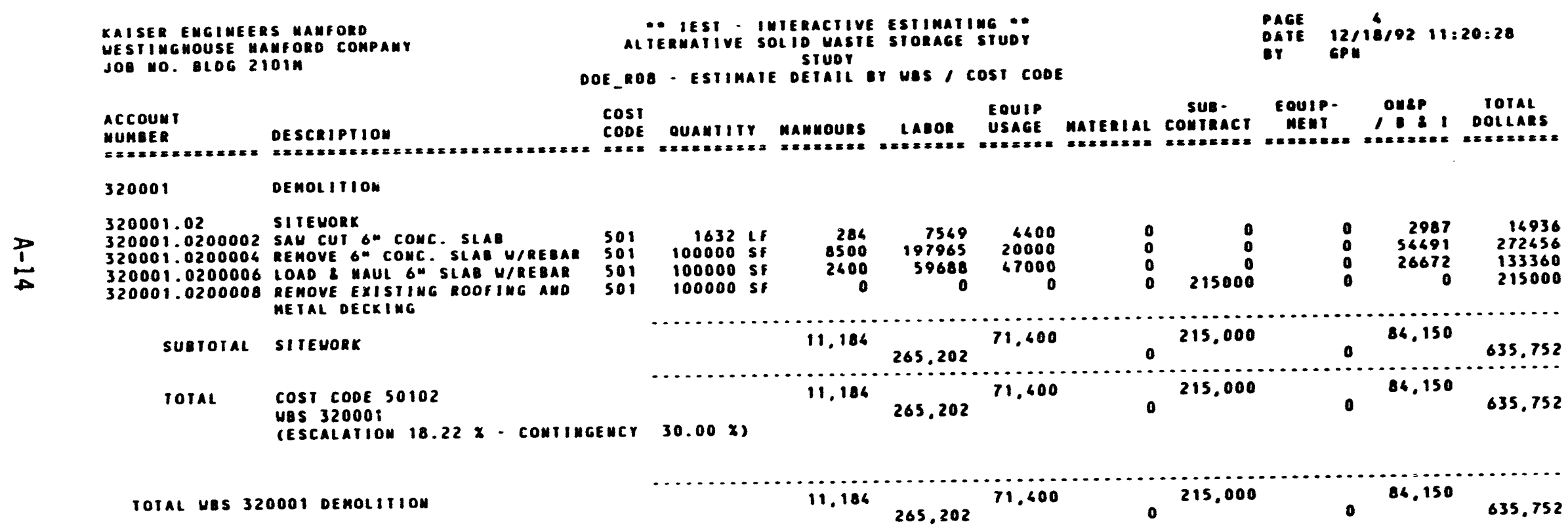




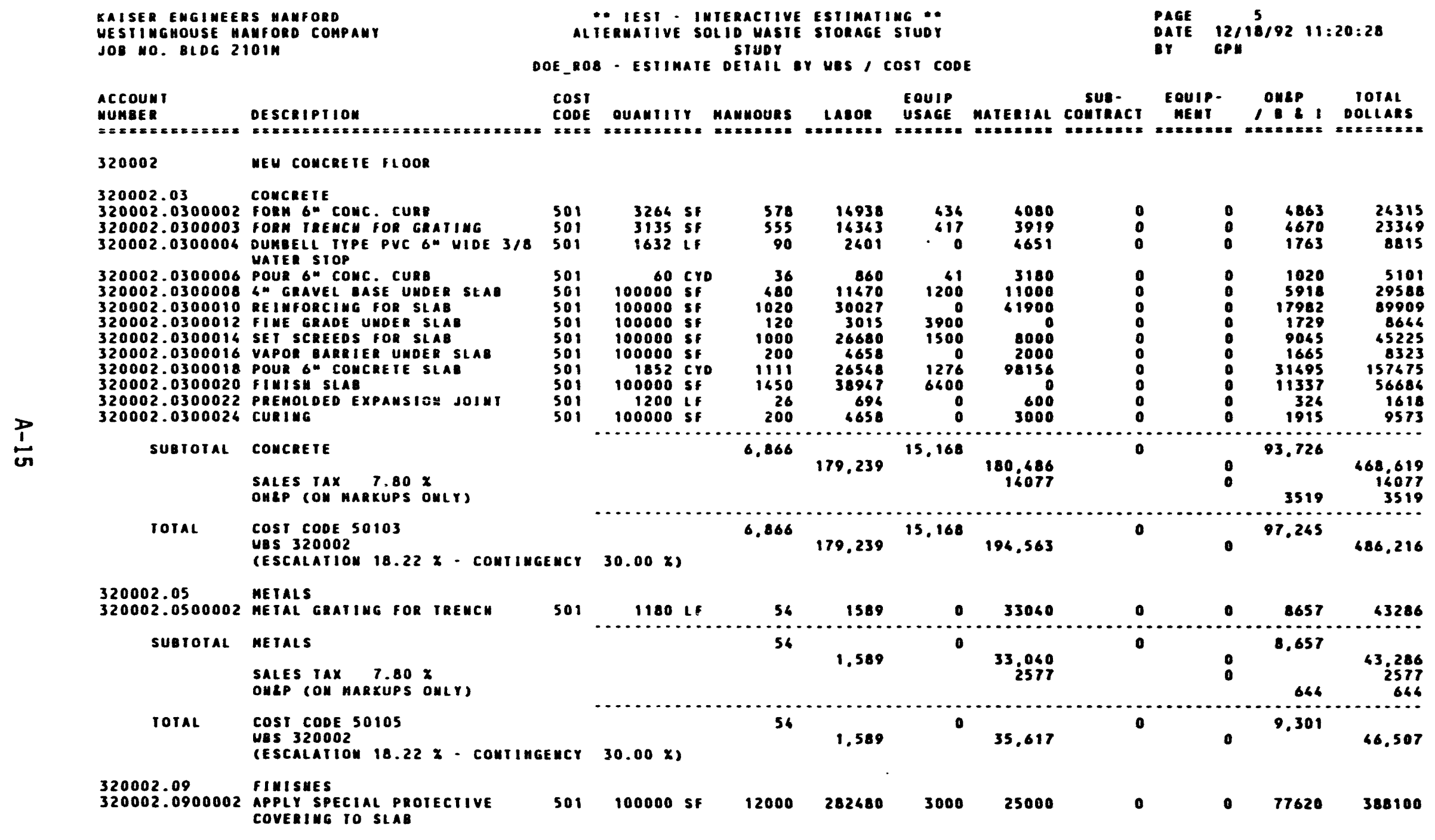




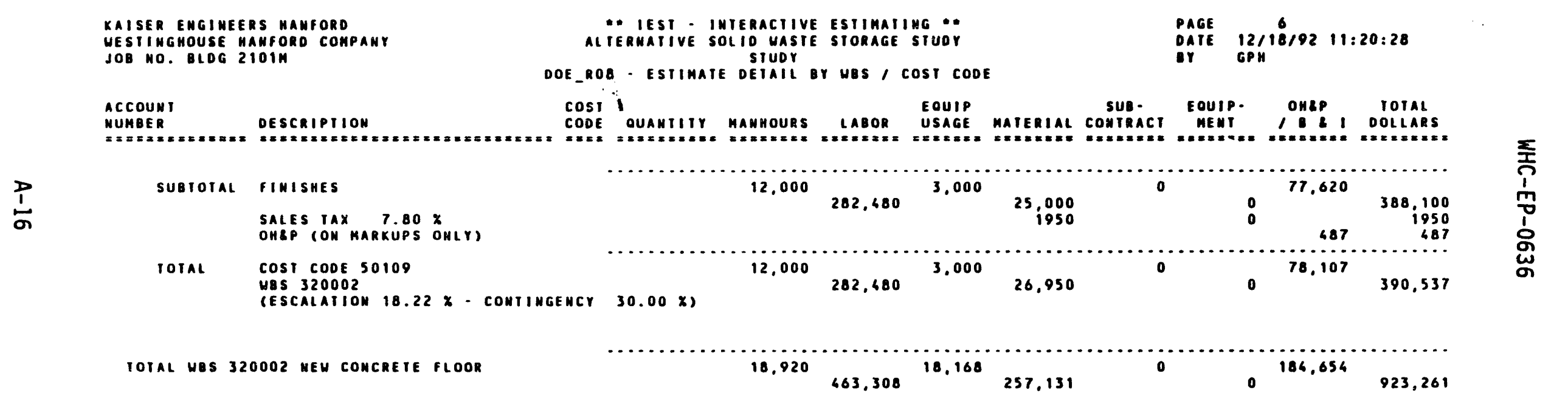




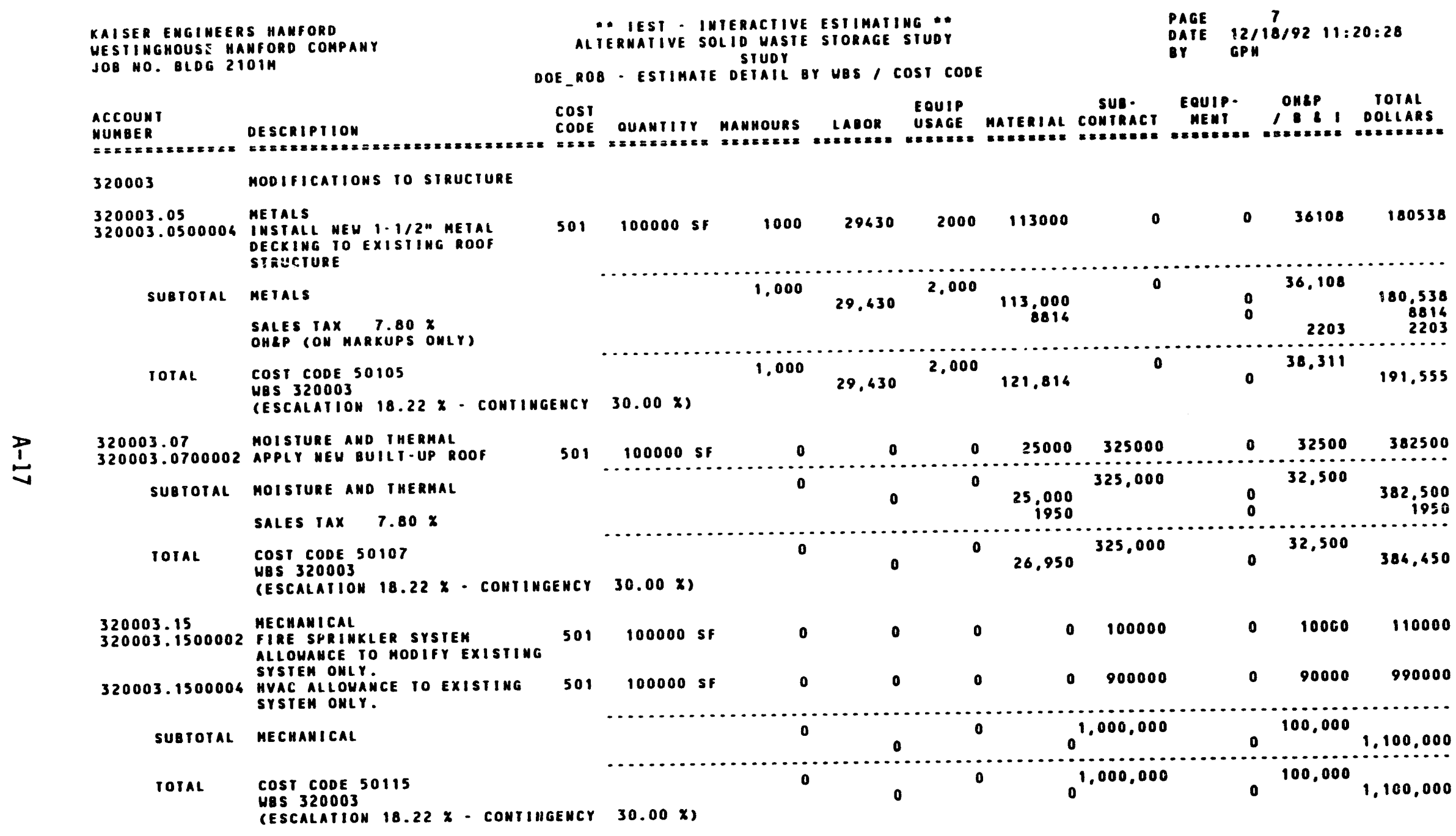




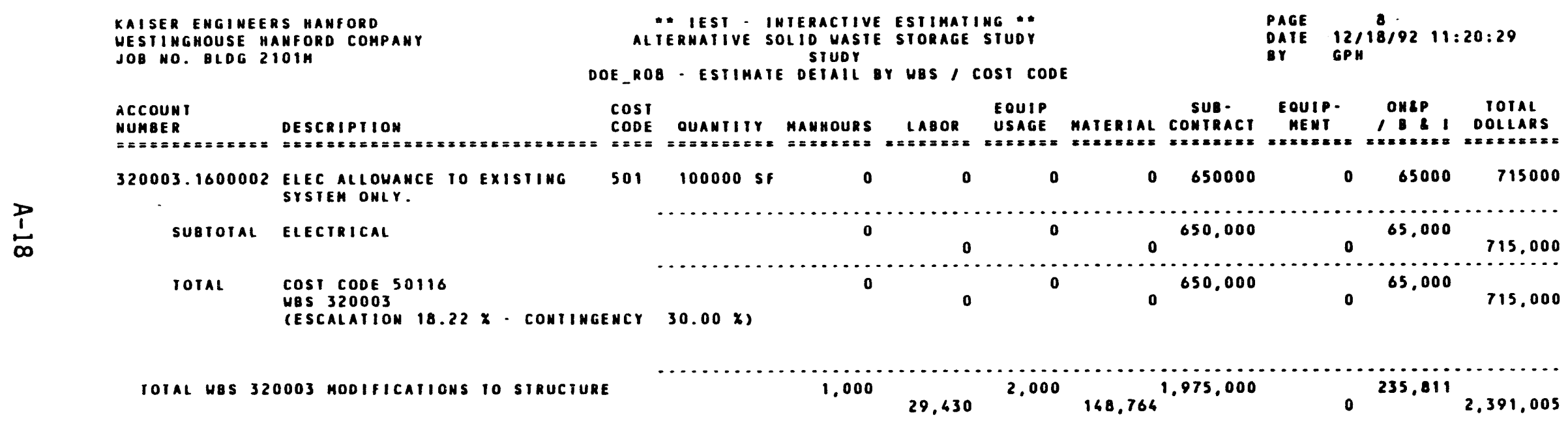




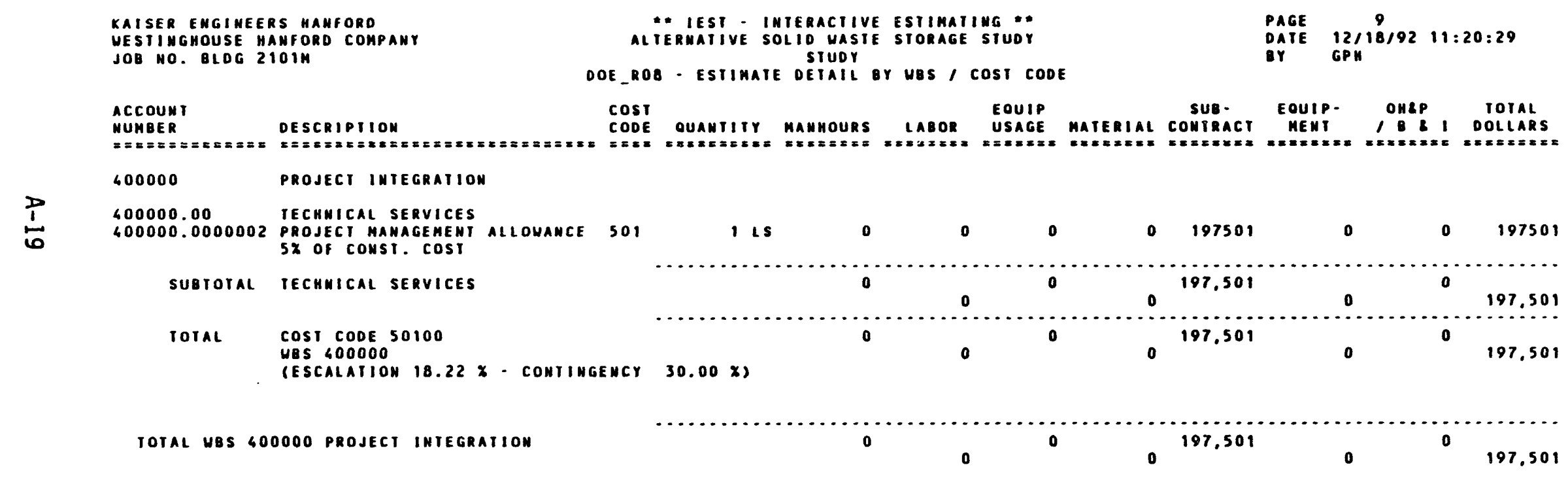




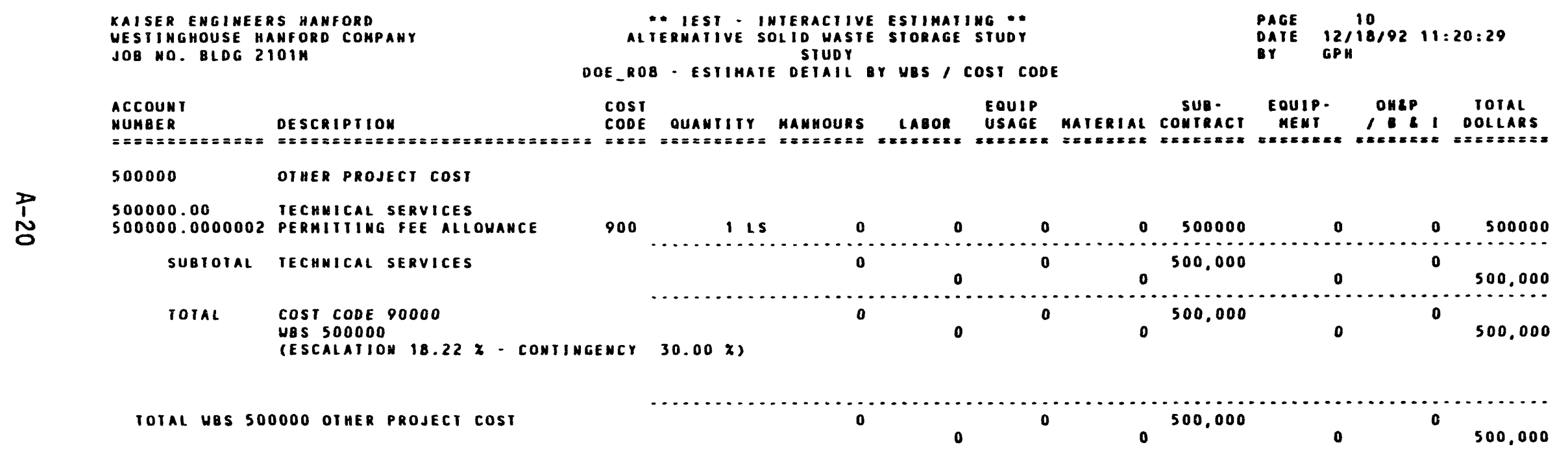


WHC-EP-0636

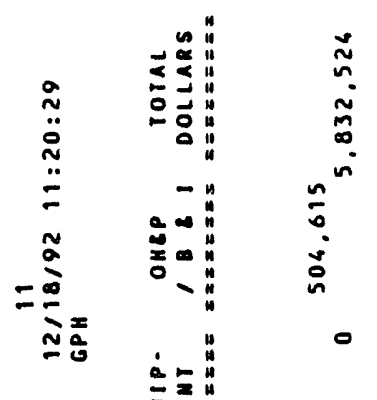

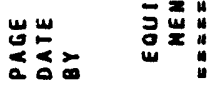

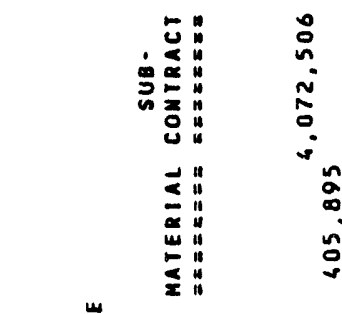

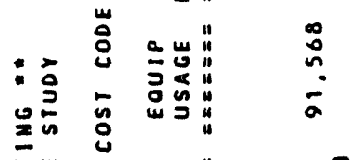

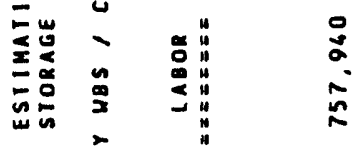

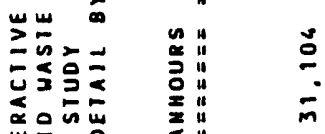

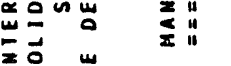

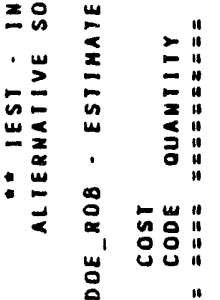

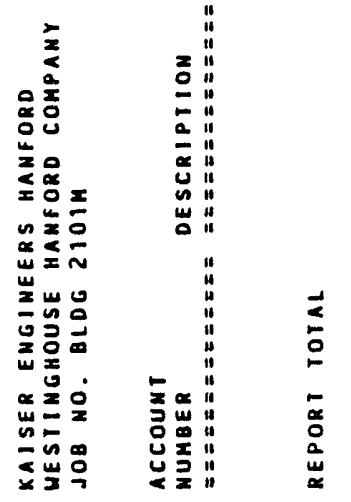

A-21 
WHC-EP-0636

This page intentionally left blank. 
WHC-EP-0636

\section{DISTRIBUTION}

Number of Coples

OFFSITE

ONSITE

25

Westinghouse Hanford Company

R. E. Barker H5-71

B. M. Barnes H6-24

S. R. Briggs G6-47

M. C. Carison B2-20

M. L. Dewitt G6-47

T. M. Greager G6-47

R. F. Guercia R3-80

M. L. Hayward H5-33

J. M. Hennig R3-80

R. D. Hodgson H5-71

M. C. Hughes R2-81

H. C. Humphrey, Jr. S2-16

W. G. Jasen N3-13

K. M. Lifikala A2-24

M. M. McCarthy N3-13

D. B. Powell, Jr. T4-03

R. J. Roberts N3-13

J. C. Sabin H5-71

S. W. Seller B4-64

RL Public Reading Room A1-65

Document Processing and
Distribution (2)

Central Files L8-04

Document Clearance Administration A3-36

PNL Technical Library K1-11 
WHC-EP-0636

This page intentionally left blank.

Distr-2 

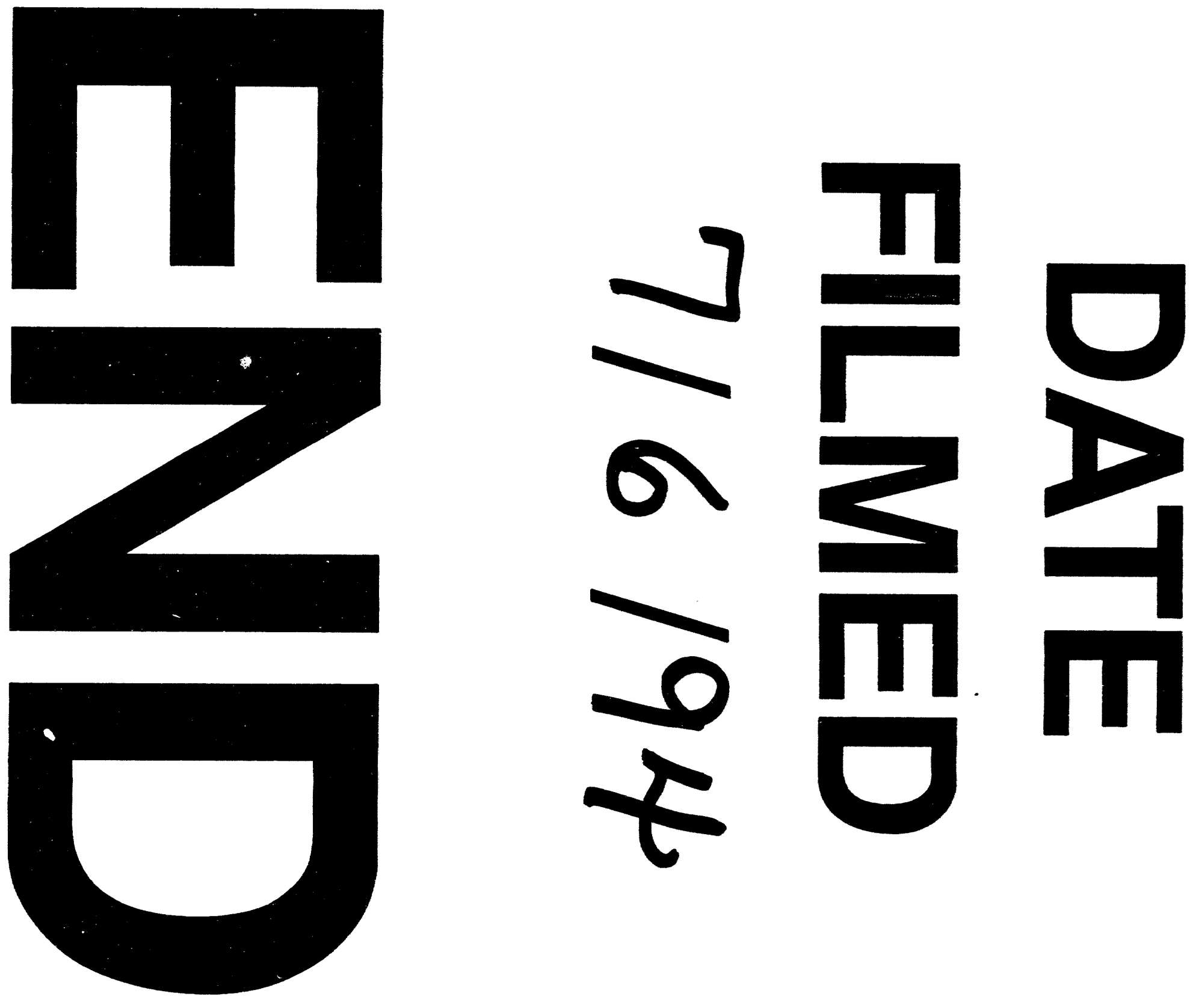
